
APAE No. 61
Copy No.
AEC Research and
Development Report
UC-81 Reactors-Power
(Special Distribution)

\title{
A SURVEY OF THE EFFECTS OF NEUTRON IRRADIATION ON THE IMPACT AND OTHER MECHANICAL PROPERTIES OF PRESSURE VESSEL STEELS FOR THE SM-2 REACTOR
}

\author{
By: \\ Richard Wm. Kelleman
}

Approved By:
R. D. Robertson, Materials Engineer

D. D. Foley, Head Materials Technology

\author{
Issued: \\ April 1, 1960
}

Contract No. AT(30-3)-326

with U. S. Atomic Energy Commission

New York Operations Office

ALCO PRODUCTS, INC.

Post Office Box 414

Schenectady 1, New York 


\section{ABSTRACT}

This report summarizes the data obtained in a recent literature survey conducted to determine the effects of neutron irradiation on the Impact and other mechanical properties of both ferritic steels and austenitic stainless steels. The survey was primarily aimed at obtaining sufficient data on the behavior of pressure vessel steels at high integrated neutron flux levels in order that a reference material of construction could be selected for the SM-2 (APPR-1B) reactor vessel.

Materials studied in this literature survey included carbon and low alloy steels such as: ASTM A-212B, ASTM A-201, ASTM A-301B (CR-Mo), ASTM A-106 (coarse and fine grained), ASTM A-285, ASTM A-302B (MnMo), ASTM A-353, ASTM A-203 Grade D, E-7016 carbon steel weld metal, USS Carilloy T-1, HY-65 and HY-80. In addition, Types 304 and 347 stainless steels were also investigated as representative austenitic materials which might be used in pressure vessel construction.

A careful evaluation was made of the irradiation induced changes in the mechanical properties of the above materials. The ferritic steels were evaluated primarily on the basis of increases in transpition temperature due to Irradiation and decreases in the amount of maximum energy absorbed prior to ductile fallure. Factors such as industrial experience, changes in other mechanical properties and the susceptibility of these materials to temper embrittlement were also considered. Austenitic stainless steels were evaluated on the basis of post-irradiation and low temperature impact strength and on irradiation induced changes in other mechanical properties.

Based upon avallable data, it is concluded that austenitic stainless steels are capable of resisting harmful property damage at integrated neutron fluxes $>1 \mathrm{Mev}$ of at least 1 to $2 \times 10^{21}$ nvt. Most carbon or low alloy steels, with the exception of ASTM A-212B, are subject to severe property damage at exposures in excess of $1 \times 10^{19}$ nvt. However, with the application of special reactor operating procedures, ASTM A-212B will be satisfactory at integrated neutron fluxes up to $5 \times 10^{19} \mathrm{nvt}$. 


\section{TABLE OF CONTENTS}

ABSTRACT

1.0 SUMMARY

2.0 INTRODUCTION

3. 0 THEORY OF IRRADIATION DAMAGE

4. 0 PROPERTY CHANGES INDUCED BY IRRADIATION $-\ldots . .-7$

4. 1 Ferritic Materials

4.1.1 Transition Temperature

4. 1.2 Nil-Ductility Transition

4.1.3 Maximum Energy Absorption -............ 11

4.1.4 Normal Mechanical Properties -............ 13

4. 2 Austenitic Stainless Steels

5.0 EVALUATION $-\ldots+\ldots+\ldots-15$

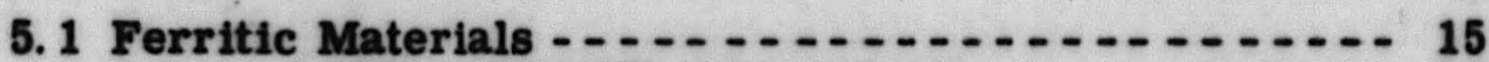

5.1.1 ASTM A-353 (9\% Nickel Steel) -........... 18

5. 1.2 ASTM A-203 Grade D (3-1/2\% Nickel Steel) -.. 19

5.1.3 ASTM A-212B and ASTM A-302B -........ 21

5. 1. 4 Welds and Heat Affected Zones -........ 24

5. 2 Austenitic Materials - .

6. 0 SERVICE PERFORMANCE -

7. 0 CONCLUSTONS

8.0 REFERENCES - 0 -

9. 0 APPENDIX - Effect of Neutron Irradiation on the Mechanical Properties of Pressure Vessel Steels - Tabular Data and Figures -.- 35 thru 73 


\section{0 SUMMARY}

As a requirement of the SM-2 (APPR-1B) reactor development program, a literature survey was conducted to determine the effects of neutron irradiation on the impact and other mechanical properties of various pressure vessel steels for possible use in reactor vessel construction. Evaluation of the irradiation induced material property changes and characteristics, as determined from sample testing, resulted in recommendation of either of the following materials for the SM-2 reactor vessel at a design life of 20 years, depending on vessel size:

1. A stainless clad carbon-silicon steel, ASTM A-212B (firebox quality), at a maximum integrated flux $>1 \mathrm{Mev}$ of $5 \times 1019 \mathrm{nvt}$, corresponding to a reactor vessel diameter of $55^{\prime \prime}$. Precautionary startup and shutdown procedures to prevent application of significant loading at temperatures less than $185^{\circ} \mathrm{F}$ would be mandatory. In addition, the base metal, weld metal and heat affected zones of a reactor vessel fabricated from ASTM A-212B would be required to conform to ASTM specification A-300.

2. An austenitic stainless steel such as Type 304 or Type 347 at a maximum integrated flux $>1 \mathrm{Mev}$ of $2 \times 10^{21} \mathrm{nvt}$, corresponding to a reactor vessel diameter of 41 ". Type 304 would be preferable to Type 347 since fabrication and weiding problems are minimized by the use of this material.

The above recommendations were further justified by the favorable results obtained from comparatively recent tests conducted on similar structural materials in the Material Test Reactor (MTR) under flux and temperature conditions equivalent to those anticipated in the SM-2.

Final selection of a reference material for the SM-2 reactor vessel was based upon metallurgical, nuclear, and mechanical design considerations. The latter two indicated a desirability of utilizing a small size reactor vessel. This narrowed the range of suitable materials to those of an austenitic type.

All ferritic materials studied in this survey were evaluated on the basis of observed increases in transition temperature due to irradiation, decreases in the amount of maximum energy absorbed prior to ductile failure, susceptibility to temper embrittlement, and changes in the normal mechanical properties. For SM-2 reactor vessel application, rejection of all these steels, with the exception of ASTM A-212B, was necessary for the following reasons:

1. ASTM A-285 - Code and other limitations for this material in thicknesses greater than 2 inches. 
2. ASTM A-106 - obtainable oniy in the form of pipe.

3. HY-65 - not available commercially.

4. HY-80 - subject to excessive increases in transition temperature at exposures of $5 \times 10^{19}$ nvt.

5. ASTM A-301B - lack of irradiation data at neutron fluxes above $5 \times 10^{18}$ nvt, and a final mid-range transition temperature of $175^{\circ} \mathrm{F}$ at this exposure.

6. USS Carilloy $\mathrm{T}-1$ - observed increases in transition temperature of $350^{\circ} \mathrm{F}$ after an exposure of $7 \times 1019 \mathrm{nvt}$.

7. ASTM A-201 - lower allowable stress value than ASTM A212B.

8. ASTM A-302B - observed increases in transition temperature of $240^{\circ} \mathrm{F}$ after an exposure of $5 \times 10^{19} \mathrm{nvt}$.

9. ASTM A-353 - subject to temper embrittlement after extended periods of holding in the $550^{\circ} \mathrm{F}$ to $850^{\circ} \mathrm{F}$ temperature range.

10. ASTM A-203 Grade D

- possibility of temper embrittlement at reactor vessel operating temperature of $550^{\circ} \mathrm{F}$.

Austenitic stainless steels were evaluated on the basis of post irradiation and low temperature impact strength, as well as irradiation indiced changes in properties such as hardness, tensile strength, yield strength and elongation. Austenitic stainless steels other than Types 304 and 347 were not considered due to the lack of irradiation data, although any stable austenitic stainless steel would probably possess essentially similar resistance to irradiation damage. 


\section{0 INTRODUCTION}

Materials used in the construction of nuclear reactor vessels are generally subjected to conditions and enviroments that are new in scope and magnitude compared to conventional non-reactor type structures. This problem has always been of major concern in the design of nuclear power plants, since the effects of neutron irradiation op the mechanical properties of structural materials can be deleterious? $(1)$ The properties of these materials can deteriorate to such a degree from the initial as-installed properties after exposure to high integrated neutron fluxes that conformance to standard specifications is no longer possible. (2) As an erample, expogure of ASTM A-106 fine grained steel(3) to an integrated flux of $1 \times 10^{20} \mathrm{nvt}$ at $200^{\circ} \mathrm{F}$ can reduce the uniform elongation from an initial value of about $20 \%$ to $5 \%$. This drastically reduced value is considerably below the minimum of $20 \%$ acceptable for this particular steel by ASTM standards.

Drastic changes in even more critical properties can also result from exposure to high integrated neutron fluxes. Transition temperature increases, for example, of as much as $350^{\circ} \mathrm{F}$ have been reported for $\mathrm{T}-1$ steel after exposure to a slightly lower flux level. Such changes in the mechanical properties of materials used in nuclear construction must be carefully considered, particularly in the design of compact reactor systems such as the SM-2 where high power outputs are required. Integrated neutron fluxes considerably greater than those obtained in previous SM-type reactors can be expected in a design of this type. Calculations of expected 20 year "nvt" values for various SM-2 reactor vessel designs varying from $31^{\prime \prime}$ to $56^{\prime \prime}$ in diameter indicate that flux levels approaching 1022 nvt may be attained, depending on the size vessel selected. (5)

Irradiation data on materials subjected to such severe exposures are not as plentiful as desired, especially at operating conditions normally encountered in nuclear power plants. Past experience in this field of irradiation testing has shown that evaluation of irradiation damage effects usually cannot be made with the degree of certainty desired due to the following limitations:

1. Lack of complete understanding of the mechanism by which irradiation damage takes place.

2. Insurficlent knowledge of the effects of elevated irradiation temperature on the properties of materials in general.

3. Complexity of the combined effects of elevated irradiation temperature, time of exposure, neutron flux, and integrated neutron Mlux. 
4. Insufficlent data on full size Chaspy Impact specimens, and lack of complete correlation wth sub-oize impact data.

5. Extreme variations in data reported by different sources for materials Irradiated under supposedly stmilar conditions.

Although the above limitations are a disadvantage, good engineering practice stili requires that selection of nuaterials for reactor vessel aplication be based upon a careful evaluation of the best data avallable. For this purpose, a literature survey was conducted to obtain all avallable data on the effects of neutron irradiation on pressure vessel steels, with the immodiate objective of selecting a suitable material for the SM-2 reactor veseel. A etudy was made of the irradiation induced property changes in both fosritic ateels and austenitic stainless: steels, as determined primarily from Charpy "V" notch or sub-size lzod energy temperature relations. 


\section{0 THEORY OF IRRADIATION DAMAGE}

Although the theory of irradiation damage to structural materials is not sufficiently advanced at present to allow a detailed quantitative analysis of the problem, experimental evidence does indicate that fast neutrons having energles greater than $1 \mathrm{Mev}$ are the nuclear particles which cause most of the damage to structural materials. (2), (3), (7) Damage by other nuclear radiations, such as beta particles and gamma rays, is considered negligible by comparison, since the momentum phich can be transferred to a lattice atom from such radiations is small. (3) Slow neutrons may be absorbed into the nucleus of a metal atom, resulting in the formation of impurity atoms which may indirectly cause irradiation damage. However, the effect of such impurity atoms introduced through neutron capture is believed to be rather small and may be ignored in relation to other damage effects, upless the integrated neutron flux attains a value of from $10^{22}$ to $10^{23}$ nvt. (3)

The rate and extent of property changes in structural materials of the types used in nuclear construction are believed to be proportional to the number of atoms displaced as a result of neutron bombardment. (6) The number of atoms displaced to vacant lattice sites or interstitial positions is in turn a function of the fast neutron flux and the length of time of exposure, as well as of the irradiation temperature and the previous history of the metal. It is believed that the tendency for atoms displaced by neutron bombardment to return to theif equilibrium position increases with increasing irradiation temperature. (6) Thus, sufficiently high temperatures may reduce the magnitude of some irradiation damage effects.

The temperatiure at which at least partial recovery from an irradiation induced property change takes place has been shown to vary with the mechanical property in question as well as with the type of material. For example, hardness, impact and other mechanical property changes in ASTM A-212B carbon silicon steel do not anneal out at the same rate or to the same extent at the temperatures expected in normal reactor operation. (3) Although some beneficial effect in most properties due to elevated reactor vessel operating temperature is expected, data on this subject is too meager at this time to permit a realistic upgrading of the structural materials evaluated in this survey. 


\section{0 PROPERTY CHANGES INDUCED BY IRRADIATION}

\section{1 FERRITIC MATERIALS}

\section{1.1 Transition Temperature}

Industrial experience with non-nuclear pressure vessels and engineering structures has demonstrated the need for proper design and materials selection to prevent brittle failure. Prevention of brittle failure is of even greater importance in reactor pressure vessels because of the property changes induced by irradiation in many structural materials. For example, with irradiated ferritic materials, one of the measurable property changes tested to date is an increase in the temperature of transition from ductile to brittle behavior. Transition temperature increases of sufficient magnitude could result in brittle failure of a reactor vessel if stress sufficient to cause localized yielding in an area containing notch defects or stress raisers is applied when the vessei temperature is in the region of brittle behavior, as judged by energy-temperature relations. (8)

Materials exhibiting extremely large increases in transition temperature should not be considered for use in reactor vesseis subject to high flux impingement since failure could then conceivably occur even at reactor operating temperatures. Transition temperature increases should be so limited that the design load will not be applied at metal temperatures conducive to brittle failure.

The transition temperature of a particular material may be defined as that temperature which is characterized by a change from a desirable plastic behavior to an undesirable brittle behavior. (9) The change may be either gradual or abrupt, depending upon the type of test specimen used to evaluate toughness and the criteria used in selecting the transition temperature. Standard specimen sizes incorporating various notch sizes and shapes have been developed, including the Charpy Keyhole notch, the Charpy "V" notch and the Izod. Sub-size Izod samples, characterized by smaller area, notch size and length, have been used mainly for applications where space in the environment being tested is limited, such as in or adjacent to the core of a testing or power reactor.

Transition temperature curves are obtained by plotting the data obtained from testing a series of sampies over a range of temperatures. Temperature is plotted as the abscissa. The amount of energy required for fracture, percent of lateral contraction at the base of the notch, $8{ }_{10}$ percentage shear of the fracture surface is usually plotted as the ordinate. (10) 
Of the various types of samples and methods of interpreting data, , the energy transition criteria of the Charpy " $V$ " notch test has been shown to provide the most significant and practical method. (10) However, Charpy "V" notch post irradiation data are extremely limited at present, as evidenced from Appendix Figure 8. The majority of data has been obtained from sub-size Izod impact specimens which are generally characterized by a gradual change from ductile to brittle behavior over a range of temperatures.

Various criteria have been used for selecting transition temperatures such as the mean of the high and low energy values, $50 \%$ of the maximum energy value, the $10,15,20$, or $30 \mathrm{ft}$. $\mathrm{lb}$. energy level, or the first significant drop in the maximum energy absorbed. (12) The criterion most widely used for comparing transition temperatures of unirradiated and irradiated materials has been the mid-point of the portion of the transition temperature curve indicating a change from ductile to brittle behavior. This method of selecting transition temperatures was used in evaluating materials studied in this literature survey.

Typical pre-and post-irradiation energy transition temperature curves(11) obtained from testing sub-size Izod specimens of ASTM A-212B are illustrated in Figure 4. 1, showing transition temperature ranges, midpoints, and increases in transition temperature due to irradiation. Similar curves have also been plotted by investigators for other carbon and low alloy ferritic materials on which post irradiation data were taken. (11)

Table 1 of the Appendix summarizes all the available energy transition data for sub-size Izod and full size Charpy " $V$ " notch specimens of various carbon and low alloy steels in both the unirradiated and irradiated conditions.

All values of integrated neutron flux reported in the Appendix tables and in the text of this report represent fast neutrons with energies greater than 1 Mev. Results of irradiation tests carried out in the NRX reactor at Chalk River, however, were based on integrated fluxes above the $500 \mathrm{ev}$ energy level. It was therefore necessary to apply a conversion factor to correlate these integrated neutron fluxes with levels above $1 \mathrm{Mev}$, since fluxes at this latter energy level are believed to cause most of the property damage to structural materials. Calculations made at Chalk River indicated that the flux above $1 \mathrm{Mev}$ was about $1 / 3$ of that above $500 \mathrm{ev}$ in the NRX reactor position used for the test samples in question. This conversion factor was used . in converting the reported Chalk River flux values from the $\mathbf{5 0 0}$ ev energy level to fluxes above $1 \mathrm{Mev}$.

Increases in transition, temperature resulting from irradiation are shown as a function of integrated fast neutron flux in Appendix Figures 2 through 4. 


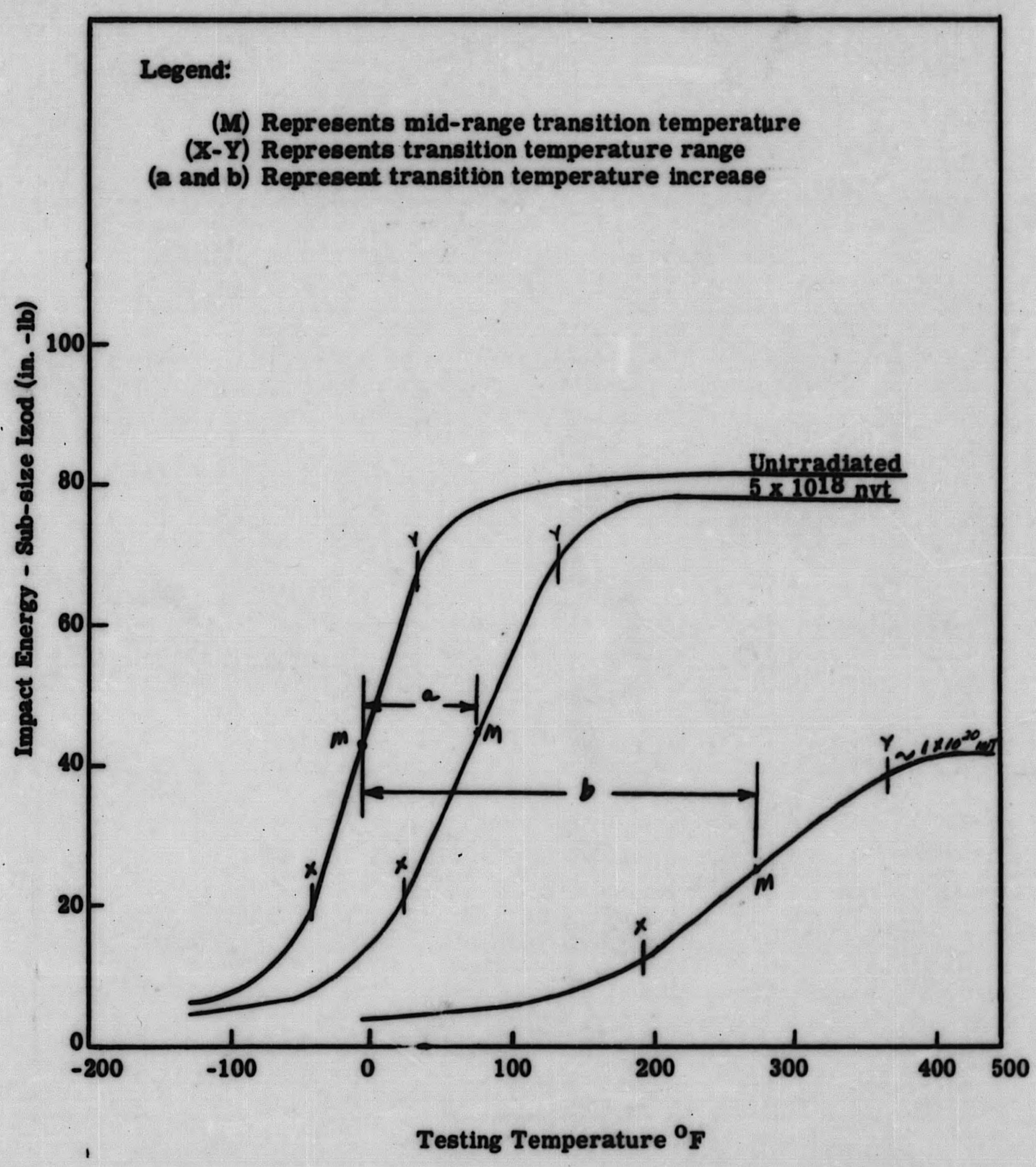

Figure 4.1 Typical Pre-and Post-Irradiation Transition Temperature Curves for Sub-Size Izod Specimens of ASTM A-212B 
Similar graphs for post-irradiation mid-range transition temperatures are shown in Appendix Figures 5 and 6. The chemical composition of materials evaluated in this survey is found in Appendix Table II.

\subsubsection{Nil-Ductility Transition}

A more accurate method of predicting brittle or non-brittle behavior is the use of the NDT (nil-dugtility transition) concept developed by the Naval Research Laboratory. (10) In this test, a relatively small test piece containing a brittle weld deposit to act as a crack starter is subjected to a sharp blow from a falling weight. This test permits laboratory determination of the temperature at which a given steel loses its ability to develop more than a minute amount of deformation in the presence of a sharp defect.

Correlation with many ferritic steels which had been subject to brittle fallure in service has indicated that the NDT tepperature was above the failure temperature in all cases by $10^{\circ}$ to $30^{\circ} \mathrm{F}$. (10) Comparison with Charpy "V" notch tests indicated that good correlation could be obtained between energy values characteristic of a given steel and the NDT temperature. With common pressure vessel materials, this NDT equivalent energy value : has been found to be $15 \mathrm{ft}$. lbs. Charpy "V" for ASTM A-212B, and $30 \mathrm{ft}$. lbs. Charpy "V" for ASTM A-302B. (13), (14)

If NDT energy values were available for ferritic materials after irradiation under conditions of reactor operation at required flux levels, the problem of predicting a safe "nvt" value would be relatively simple. Unfortunately, such NDT values are not available, as reported impact energy work has been limited to determination of transition temperatures or transition temperature increases. Limited unpublished data, however, does show that for several irradiated materials, good correlation exists between transition temperature increases determined from Charpy " $V$ " notch data and increases in NDT temperature as determined by drop weight tests. (15) This linear relation, shown in Appendix Figure 7, indicates that no unusual change in the energy-NDT relation results from exposure to irradiation.

The NDT concept is of added value in that assurance is given to the use of mid-range transition temperatures as a basis of evaluation, since the NDT temperatures for recommended materials are well below, the mid-point of the transition temperature curve in the unirradiated condition. (10)(13)

\section{1. 3 Maximum Energy Absorption}

Another irradiation induced change in energy-temperature relations characteristic of many ferritic materials is a lowering of the maximum 
energy absorbed in ductile fallure. If this occurs, the upper plateau of the energy transition curve, is shifted downward and to the right by increasing doses of fast neutrons. (16) No correlation of this shift of ductile energy value with other material properties is available at present. It may be possible, however, for brittle failure to occur in a material after irradiation if the upper plateau of the energy transition curve is reduced to a level considered unacceptable for unirradiated material. In other words, a significant shift may reduce the energy value of the normally ductile portion of the curve to a level less than that corresponding to the NDT temperature for a particular material. This condition is illustrated schematically in the following figure:

\section{FIGUR E 4. 2}

Effect of Neutron Irradiation on the Maximum Energy Absorbed in Ductile Failure

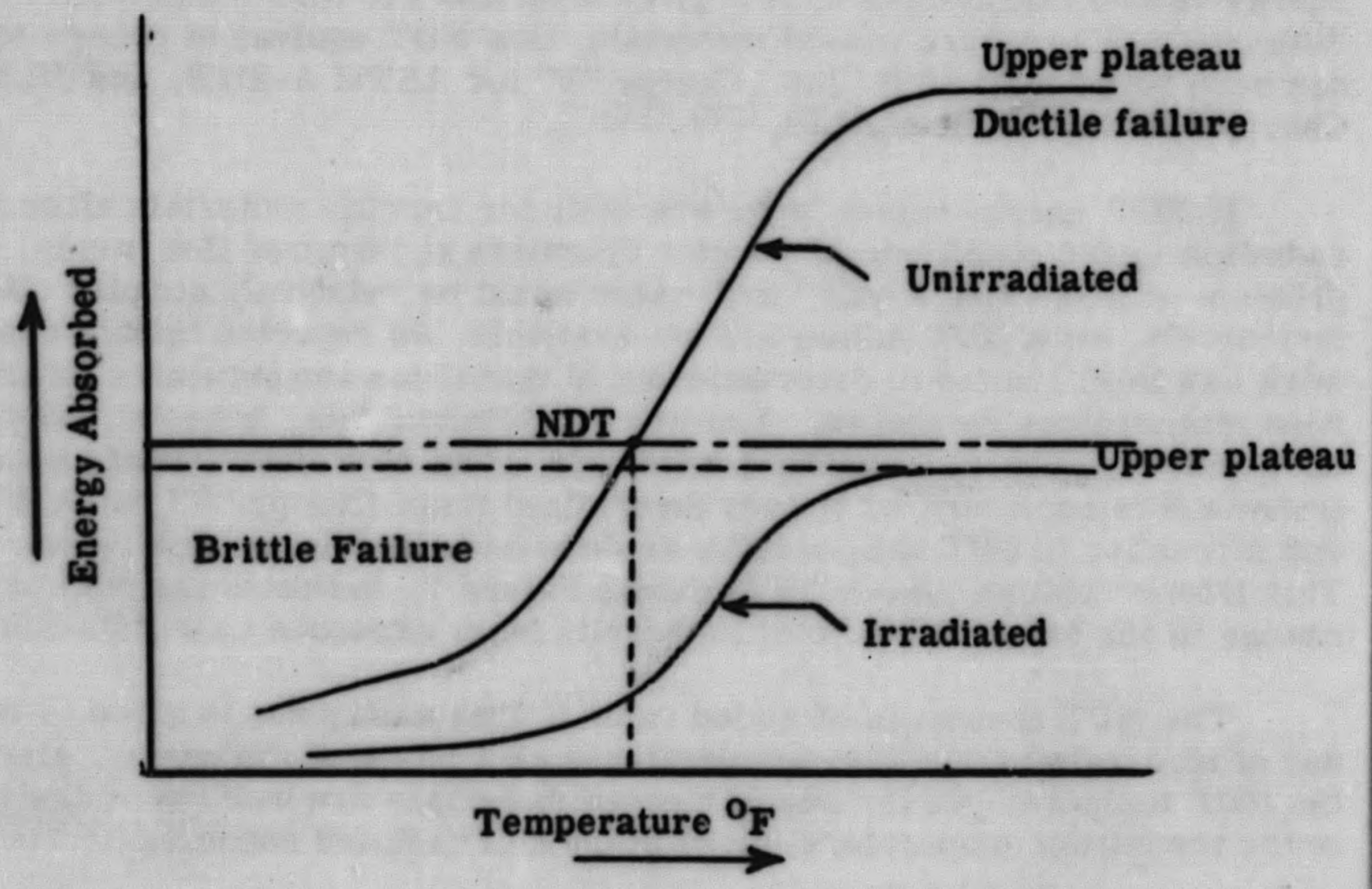

In the absence of data proying otherwise, it is presumed that an occurrence of this nature would indicate brittle behavior even though the upper plateau normally represents the ductile portion of an energy transition curve. 


\subsection{Normal Mechanical Properties}

The normal mechanical properties of ferritic steels, as judged by conventional sub-size tensile tests, are also subject to irradiation induced changes. Properties measured in these tests include ultimate tensile strength, yield strength, reduction in area, and elongation. Other data have shown that, in some cases, gross grain refinement can occur in a metal structure as a result of irradiation. (17)

The validity of predicting satisfactory service of a reactor vessel on the basis of such mechanical and structural property changes is questionable. Brittle failures in non-reactor service have been shown to correlate with energy temperature relations and with absolute energy values rather than with tensile tests. Normal mechanical property tests, however, still remain as one of the bases for acceptance of pressure vessel materials.

Actual data correlating post irradiation mechanical properties as determined by tensile testing with service performance is practically nonexiŝtent. Until such data are available, mechanical property data obtained by conventional tensile testing will be of greatest value in determining compliance of structural materials to established commercial specifications. Pre-and post-irradiation mechanical properties for a few of the ferritic steels studied in this survey are found in Table 3 of the Appendix.

\subsection{AUSTENITIC STAINLESS STEELS}

Stable austenitic stainless steels, being essentially síngle phase alloys, differ from ferritic materials in that a ductile-brittle transition is not encountered in the unirradiated condition, even at temperatures as low as $-320^{\circ} \mathrm{F}$. Similar behavior is found in irradiated material at reported maximum exposures of $4 \times 10^{19}$ nvt. Energy temperature relations for irradiated austenitic stainless steels are characterized by a very gradual sloping curve and by ductile fracture of test specimens. Although no reported impact data are available above $4 \times 10^{19}$ nvt, no change in the ductile characteristics of austenitic stainless steels would be expected until an exposure in the order of $10^{22}$ to $10^{23}$ nvt is attained. At these high exposures, significant changes in alloy properties might be possible as a result of gross atomic transmutations. At the maximum exposure contemplated for the SM-2 reactor vessel, $1 \times 10^{21}$ nvt, stable austenitic stainless steels should therefore behave in a ductile manner.

Ductile behavior of austenitic stainless steels may also be predicted on the basis of other mechanical property tests. Comparison of the pre-and post-irradiated mechanical properties of austenitic stainless steels, as shown 
in Appendix Table 7, with ferritic materials, as illustrated in Appendix Table 3, indicates a significant difference in material behavior. Ferritic materials at relatively low exposures (1019 to $10^{20}$ nvt), exhibit drastic changes in ductile properties, even to the point where ductility has practically disappeared. Austenitic stainless steels, on the other hand, exhibit good retention of ductility at much higher exposures. At the maximum exposure reported, $3.76 \times 10^{21} \mathrm{nvt}(>1 \mathrm{Mev})$, for example, a post-irradiated elongation of $32 \%$ was noted for Type 347 stainless steel. As judged by all available data, the irradiation damage resistance of stable austenitic stainless steels is far superior to that of ferritic steels. 


\section{O EVALUATION}

\subsection{FERRITIC MATERIALS}

Mid-range transition temperatures and transition temperature increases after irradiation were used as the primary means of evaluating ferritic materials for possible application in an SM-2 reactor vessel, since the prevention of brittle failure is believed to be the foremost consideration. Predication of post-irradiation NDT energy values was used as a supplementary means of evaluation.

All ferritic materials considered, with the exception of ASTM A-353, ASTM A-203 Grade D, ASTM A-212B, and ASTM A-302B were eliminated due to the generally unfavorable irradiation behavior as well as other considerations. Suitability of these four promising ferritic materials for SM-2 application is discussed in detail in the sections which follow.

ASTM A-285 carbon steel was automatically eliminated from further consideration due to code and other limitations for thicknesses greater than 2 inches. A carbon steel reactor vessel considerable greater than 2 inches thick would be required for the SM-2.

ASTM A-106 was also ruled out, since the form of material required for reactor vessel fabrication is not obtainable under this carbon steel pipe specification. However, the irradiation data obtained on this particular grade of steel was helpful in determining the effects of high neutron exposure on carbon steels as a whole.

HY-65 alloy, developed initially for Navy applications, was eliminated since this material is not available commercially. HY-80 alloy, which has a slightly higher yield strength than HY-65, was also eliminated in this evaluation. Although this material is obtainable under ML specifications, its use has been limited strictly to special Navy applications and it is subject to excessive increases in transition temperature at expcsures of $5 \times 10^{19}$ nvt.

ASTM A-301B, a Cr-Mo steel, was eliminated due to the lack of irradiation data at neutron fluxes above $5 \times 10^{18} \mathrm{nvt}$. Data available at this exposure level indicated that final mid-range transition temperatures as high as $175^{\circ} \mathrm{F}$ are encountered. This is about the maximum allowable for SM-2 application at considerably higher flux levels.

USS Carilloy T-1, a quenched and tempered high strength alloy steel, appeared somewhat favorable for the SM-2 reactor vessel since it has a low unirradiated mid-range transition temperature in the vicinity of -175 . 
However, increases in transition temperature close to $350^{\circ} \mathrm{F}$ have been experienced with this alloy after an exposure of about $7 \times 10^{19} \mathrm{nvt}$.

ASTM A-201, although similar to ASTM A-212B from the standpoint of resistance to irradiation damage, was not considered further due to its lower allowable stress value. Final mid-range transition temperatures approaching $175^{\circ} \mathrm{F}$ were noted for ASTM A-201 after exposures of approximately $5 \times 10^{19}$ nvt.

Transition temperatures used in evaluating the various ferritic materials were determined from Charpy "V" notch energy temperature relations because data of this type represents the best available correlation with prevention of trittle failure to date. (10)(13) The use of this concept, however, has required utilizing some correction factors because of the very limited amount of data available for full sized impact specimens. Table 5.1 illustrates the final midrange transition temperatures based on sub-size Irod values, corrected $\mathbf{s o}$ as to represent Charpy " $V$ " notch transition temperatures expected after irradiation for the four most promising ferritic materials studied in this survey. The unirradiated mid-range transition temperatures shown in this table are representative of those obtainable from commercially available materials.

The maximum transition temperature considered allowable for ferritic materials after irradiation is in the range of $185^{\circ} \mathrm{F}$ to $200^{\circ} \mathrm{F}$. This limit is determined by ease of operational practices in start-up and shut-down of a reactor to prevent application of significant stresses at low vessel temperatures. Limiting nvt values were therefore determined by a maximum mid-range transition temperature of $185^{\circ} \mathrm{F}$ after irradiation.

The post-irradiation transition temperature for a given material is essentially equivalent to the initial transition temperature plus the increase induced by irradiation. Initial transition temperatures are known to vary with different materials and with processing variables in any given material. Although it is desirable to select a material with an initial transition temperature as low as possible, the temperature used should be representative of commercially available materials. ASTM A-212B, for example, can be procured to ASTM A-300 which requires a minimum of $15 \mathrm{ft}$. lbs. Charpy keyhole at $-50^{\circ}$. This is equivalent to approximately $15 \mathrm{ft}$. ibs. Charpy "V" at $+10^{\circ} \mathrm{F}$, (15)(18)(38) Since the unirradiated Charpy "V" notch transition curve customarily exhibits a practically perpendicular slope for this material, this temperature can be conservatively established as the initial Charpy "V" notch transition temperature for ASTM A-212B.

ASTM A-302B has a similar transition temperature if procured to a $30 \mathrm{ft}$. 1b. Charpy " $\mathrm{V}$ " at $+10^{\circ} \mathrm{F}$. Although this material is not obtainable under ASTM specification A-300, it has been procured to the above energy-temperature relationship under a somewhat similar specification for Navy applications. (18) Initial transition temperatures for AST M A-353 (9\% nickel steel) 


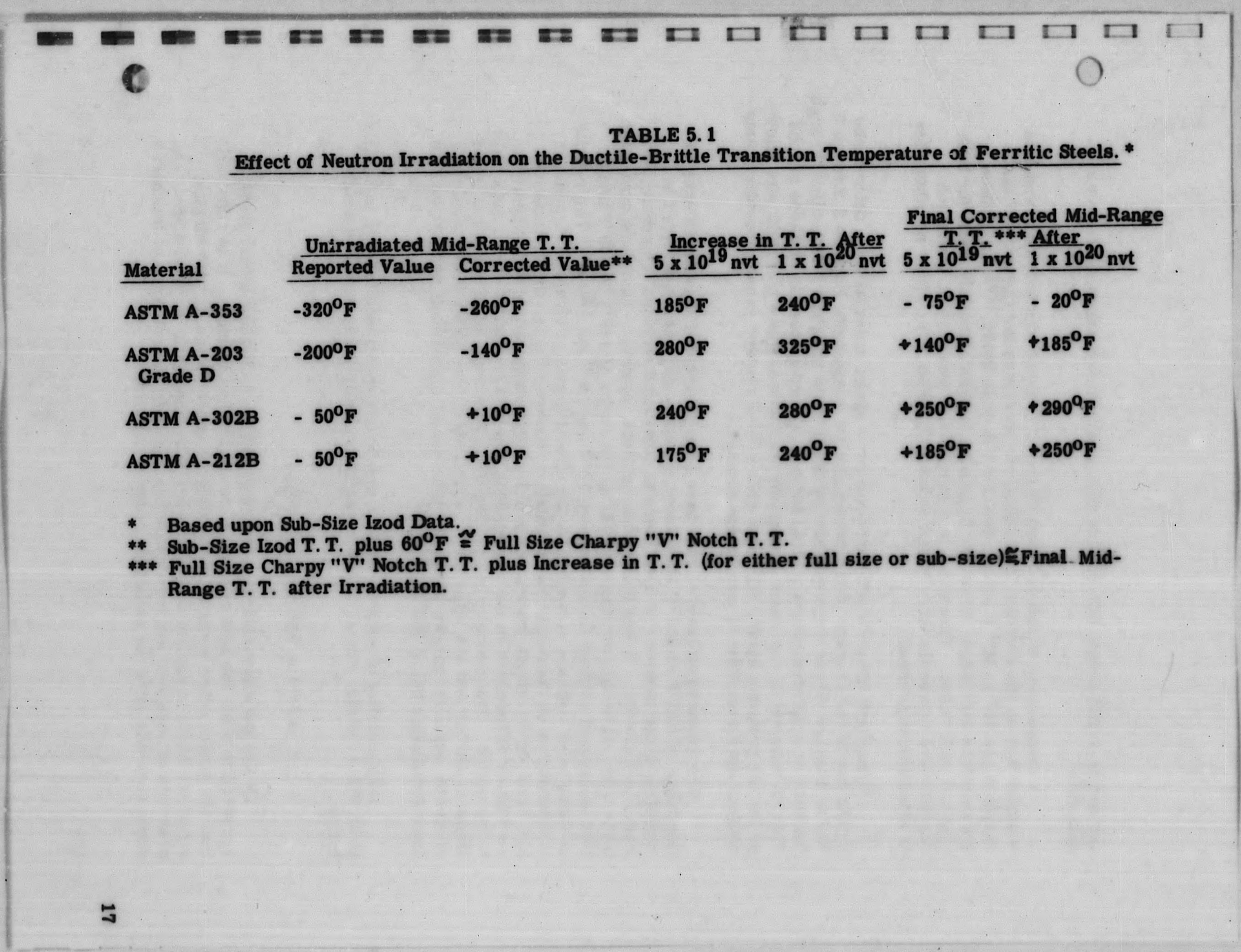


and ASTM A-203 Grade D(3-1/2\% nickel steel) were determined from avallable data.

A comparison of unirradiated Charpy "V" notch and sub-size Izod data indicate that on the average, transition temperatures for Charpy " $V$ " notch samples are $50^{\circ}$ to $60^{\circ} \mathrm{F}$ higher than for sub-size Izods. (19) Transition temperature increases, however, appear to be approximately equal for both types of specimens. Therefore, for purposes of evaluation, transition temperature increases were based on sub-size Izod data, since no other data is available at present.

Transition temperature increases for a given material were determined by the use of the average of the values plotted in Appendix Figures 2 through 6. These average values were obtained by drawing an imaginary centerline through the band of scattered values plotted for the various materials on these graphs. This is believed to represent conservative practice, since no credit was allowed for the probable beneficial effect of the SM-2 reactor vessel operating temperature upon reduction of irradiation damage.

The majority of tests to date have been performed at temperatures in the range of $100^{\circ} \mathrm{F}$ to $200^{\circ} \mathrm{F}$ because of the many difficulties involved in irradiating large numbers of specimens at controlled elevated temperatures in high flux reactors. A limited number of tests, however, have been conducted on ferritic materials at temperatures in the range of $440^{\circ} \mathrm{F}$, to $800^{\circ} \mathrm{F}$ and at fast integrated neutron fluxes between $10^{18}$ and $10^{20}$ nvt. (3), (20) The results of these tests indicate variations in the effectiveness of elevated irradiation temperatures on annealing out ir radiation damage effects. Such variations are believed to reflect inaccuracies in flux and temperature measurements as well as differences in the composition and heat treatment of the materials being tested. The majority of existing data, however, does show that irradiation of carbon and low alloy steels at temperatures above $500^{\circ} \mathrm{F}$ generally produces smaller changes in impact and normal mechanical properties than does irradiation below $200^{\circ} \mathrm{F}$. (3), (20)

Applicability of each of the four previously mentioned ferritic materials to an SM-2 reactor vessel is discussed individually in the sections which follow.

\section{1 ASTM A-353 (9\% Nickel Steel)}

Of the low alloy materials reviewed, ASTM A-353 (9\% nickel steel) appeared to offer the best resistance to irradiation damage. It is reported that the nickel added as an alloying element converts the normal ferritic structure found in carbon steels to a partially austenitic structure. (2i) The presence of austenite can materially contribute to the retention of toughness, since austenite does not embrittle under irradiation. 
An unirradiated mid-range transition temperature of about $-320^{\circ} \mathrm{F}$ was found to be characteristic of this alloy. (22) This is much lower than that observed for any other ferritic material. Even after exposure to an integrated neutron flux of $1 \times 10^{20}$ nvt, ASTM A-353 still possessed a midrange transition of approximately $-20^{\circ} \mathrm{F}$.

Although ASTM A-353 steel appeared promising from the standpoint of favorable impact strength and low mid-range transition temperature after irradiation at temperatures $\angle 200^{\circ} \mathrm{F}$ and exposures as high as $1 \times 10^{20}$ nvt, other data indicated that unirradiated material of this composition was subject to an embrittling effect in the temperature range of about $550^{\circ} \mathrm{F}$ to $850^{\circ} \mathrm{F}$. A plot of impact energy vs. tempering temperature in Appendix Figure 11 shows a decided drop in impact strength to about $50 \%$ of the initial impact energy value in this temperature range. The post-tempering value, however, is considerably above the probable nil ductility temperature equivalent of approximately $30 \mathrm{ft}$. lbs.

Long term exposure at a temperature of $700^{\circ} \mathrm{F}$ shows a similar but greater decrease in energy absorption. After a heat treatment similar to that required in fabricating a reactor pressure vessel, average impact values of $100 \mathrm{ft}$. lbs. were obtained. Subsequent holding at $700^{\circ} \mathrm{F}$ for periods of 6,000 and 7,000 hours reduced the average value to 48 and $44 \mathrm{ft}$. lbs. respectiveiy. (23) Transition temperature, as judged by $15 \mathrm{mil}$ lateral contraction, is also markedly increased by long exposures at $700^{\circ} \mathrm{F}$, as shown in Appendix Table 4.

Although no long term data are avatlable, it is probable that similar embrittling effects of an unknown degree of severity would be observed at the reference SM-2 reactor vessel temperature of approximateiy $550^{\circ} \mathrm{F}$, based on tempering data. For this reason, and because of the lack of extensive industrial experience in the non-nuclear field, ASTM A-353 cannot be recommended for SM-2 use even though resistance to irradiation damage appears to be excelient.

\section{1. 2 ASTM A-203 Grade D (3-1/2\% Nickel Steel)}

ASTM A-203 Grade D also appeared promising in its ability to resist irradiation damage. This material, however, may also be subject to embrittlement after long time holding at SM-2 reactor vessel temperature.

Table 5 of the Appendix indicates a severe increase in transition temperature after an exposure of approximately 1 year to a temperature of $700^{\circ} \mathbf{F}$. Although similar exposure at $500^{\circ} \mathbf{F}$ did not result in a transition temperature increase, the possibility of embrittlement at the reactor vessel operating temperature of approximately $550^{\circ} \mathrm{F}$ still exists. 
Since the factor of safety for ASTM A-203 Grade D after irradiation is much less than for ASTM A-353, as judged by transition temperature increases, only a relatively slight embrittling effect from long time temperature exposure could be deleterious. Consequently, ASTM A-203 Grade $D$ could not be recommended for $\$$ M-2 reactor vessel application. 


\subsection{ASTM A-212B and ASTM A-302B}

Of the carbon steels studied in this survey, more data was found to be available on ASTM A-212B than on any other ferritic material. Several subsize energy transition curves have been reported for ASTM A-212B at flux levels as high as $1 \times 10^{20}$ nvt, while apparently only one investigation has been made of the behavior of ASTM A-302B at or near this level.

Reference to Table 5.1 of the text indicates that, based upon a realistic evaluation of the data available, both ASTM A-302B and ASTM A-212B can be expected to undergo substantial increases in transition temperature at the higher flux levels. However, the expected increase of $175^{\circ} \mathrm{F}$ for ASTM A-212B at the limiting flux value of $5 \times 10^{19}$ nvt can be negated by the use of special operating procedures which are customarily applied to practically all high flux long life reactor vessels constructed of ferritic materials. ASTM A-302B, on the other hand, undergoes an increase in transition temperature of about $240^{\circ} \mathrm{F}$ after the same exposure of $5 \times 10^{19}$ nvt. An increase of this order of magnitude is higher than that considered feasible even with the application of special precautionary startup and shutdown procedures. Thus, from the standpoint of increase in transition temperature, ASTM A-212B is the only carbon steel which can be recommended for the SM-2 reactor vessel at present. Although a $185^{\circ} \mathrm{F}$ startup temperature was used as the basis for establishing a limiting flux value for this material, a further factor of safety could be added by employing temperatures as high as $200^{\circ} \mathbf{F}$.

Final recommendation of ASTM A-212B as the most satisfactory carbon steel for the SM-2 reactor vessel was also based upon maximum energy absorption relations at various flux levels, and the resistance of this material to temper embrittlement after extended periods of holding at SM-2 reactor vessel operation temperature.

Maximum energy absorption data as shown in Table 5.2 of the text, have been reported for full-size Charpy " $V$ " notch specimens of AST M A-212B and ASTM A-301B after irradiation by ORNL to a maximum integrated flux of $5 \times 10^{18} \mathrm{nvt}$ at $175^{\circ} \mathrm{F}$ and $575^{\circ} \mathrm{F}$. At the higher test temperature, the decrease in maximum energy absorption for ASTM A-212B supplied in three different heat treatments was about $15 \%$, compared to a $40 \%$ decrease observed for ASTM A-301B. (20) The midrange transition temperature for ASTM A-212B remained at approximately the same energy level as for the unirradiated material. The mid-range transition temperature of ASTM A301B, however, was reduced by about $50 \%$. Somewhat greater reductions were observed for the low temperature irradiations. 
TABLE 5.2

MAXIMUM AND MID-RANGE ENERGY VALUES FOR CHARPY "V" NOTCH IMPACT SPECIMENS OF ASTM A-212B AND ASTM A-301B BEFORE AND AFTER IRRADIATION AT $5 \times 10^{18}$ NVT AND $575^{\circ} \mathrm{F}$

\begin{tabular}{|c|c|c|c|c|}
\hline \multirow[b]{2}{*}{ Material } & \multicolumn{2}{|c|}{ Max. Energy in Ft. Lbs. } & \multicolumn{2}{|c|}{ Mid Range Energy in Ft. Lbs. } \\
\hline & Irrad. & Unirrad. & Irrad. & Unirrad \\
\hline ASTM A-212B & $30-78 *$ & $35-92 *$ & $20-50 *$ & $20-50 *$ \\
\hline ASTM A-301B & 35 & 60 & 20 & 38. \\
\hline
\end{tabular}

*Varied with the initial heat treatment

With the use of the NDT-Charpy "V" energy value of $15 \mathrm{ft}$. lbs. as the criterion of acceptance for ASTM A-212B, this material would be considered satisfactory at the above exposure. Although no NDT energy value is available for ASTM A-301B in the unirradiated condition, $30 \mathrm{ft}$. lbs. would be expected as a representative value on the basis of its similarity to other low alloy steels. Based on this NDT criterion, ASTM A-301B would then be considered borderline or below after irradiation at $5 \times 1018 \mathrm{nvt}$.

This ORNL data represents practically all full size Charpy impact tests reported to date, with the exception of one or two tests conducted on ASTM A-302B at approximately the same exposure. (26)(31) However, considerable sub-size Izod energy temperature data are available for some ferritic materials at nuxes as high as $1 \times 10^{20}$ nvt. Although no correlation exists between full size and sub-size specimens at present, it can be predicted from available energy-temperature curves that the relative reductions in maximum energy for both types of specimens will be approximately equal. Thus, at any integrated flux level for which sub-size Izod energy temperature data are available, application of the corresponding maximum energy reduction to the maximum energy value representative of unirradiated full size Charpy impact specimens will then allow comparison with the NDT-energy criterion.

Reference to Appendix Figures 9 and 10 shows the percentage decrease in maximum energy absorbed due to irradiation of sub-size Izod specimens of various ferritic materials. This data indicates that a reduction in maximum energy absorption of about $40 \%$ is characteristic of ASTM A-212B and about $45 \%$ for ASTM A-302B after exposure to an integrated neutron flux of about 4-5 $\times 10^{19} \mathrm{nvt}$. Assuming that reductions of this order of magnitude are approximately equivalent to that which can be expected for full size 
Charpy "V" notch specimens, final maximum energy values ranging from 27-34 ft. Ibs. would result for ASTM A-302B, and from 21-55 ft. lbs. for ASTM A-212B. These final maximum energy values are based upon an unirradiated maximum energy absorption of 35-92 ft. lbs. for ASTM A-212B and of 50-65 ft. Ibs. for ASTM A-302B as reported in ORNL data. (20) It is assumed that these ORNL values are representative of commercially available materials.

Thus, comparison of the maximum energy values expected after irradiation with the NDT energy criterion of $\mathbf{3 0} \mathrm{ft}$. lbs. considered acceptable for ASTM A-302B and $15 \mathrm{ft}$. Ibs. for ASTM A-212B indicates that the former material would be borderline or below at this exposure. ASTM A-212B, on the other hand, would be considered satisfactory.

In general, ASTM A-212B can be expected to possess better resistance to irradiation damage than ASTM A-302B, based upon this NDT - maximum energy absorption relation alone. Although both materials undergo essentially similar percentage reductions in maximum energy absorption after exposure to integrated neutron fluxes of about 4-5 x 1019 nvt, the 2:1 ratio of NDT energy values would require ASTM A-302B to posses approximately double the unirradiated maximum energy of ASTM A-212B for equivalent resistance to irradiation damage.

Another factor considered in the evaluation of ASTM A-212B and ASTM A-302B for possible use in reactor vessel construction was the susceptibility of these two ferritic materials to temper embrittlement. Numerous tests conducted by the Pressure Vessel Research Committee (23), (24), (25), (36), (37) indicated that these two materials are not slubject to temper embrittlement as are some of the other ferritic materials, even after extended periods of holding in the $500^{\circ}$ to $700^{\circ} \mathrm{F}$ temperature range. Similar tests conducted by other investigators revealed identical resuits.

It may be concluded that, based upon available data, ASTM A-212B is the ferritic steel which can best be recommended at this time for SM-2 reactor vessel construction. The preponderance of relatively favorable energy temperature data permits more confidence in the use of ASTM A212B carbon steel than any other ferritic material. 


\section{1:4 Welds and Heat Affected Zones}

The largest areas of uncertainty in the prediction of resistance of ferritic steels to irradiation damage is in the behavior of welds and associated heat affected zones. Although data again are extremely limited, the largest increases in transition temperature have been associated with these two requisites of fabrication of pressure vessels. The most unusual effects of irradiation damage also have occurred in welds. For example, fracture has taken place in isolated instances without necking after only a few percent plastic deformation. (26) This phenomenon is of concern because such material will not behave like an engineering material, but rather will have the properties of some new and unknown material with which industry has had no experience.

Although some heat affected zone irregularities would possibly be expected to a limited extent because of high metal temperatures and associated grain coarsening attained in welding, and because the tempering effect of subsequent weld passes is not as thorough as furnace treatment, no ready explanation is available for the behavior of cast metal (27) (characteristic of weld deposits) other than differences from directional or other properties which are characteristic of wrought material. A more clear-cut understanding of the behavior of weld metal deposits must await further testing.

Welding usually cannot be eliminated from pressure vessel manufacture. In some instances, however, the use of welded joints in high flux areas can be minimized. In any event, the best protection against excessive irradiation damage at this time is the specification requirement that welds and heat affected zones must meet the same low vessel temperature impact energy requirements as the base metal.

As in other SM reactors, it is recommended that samples of the actual materials used in reactor vessel construction be inserted adjacient to the core so as to allow energy-temperature testing of the materials concurrently with actual use. Since such samples are exposed to actual reactor operating conditions, confidence can be placed in predicting the effects of irradiation upon the reactor vessel itself as judged by the property changes exhibited by the test samples.

\section{2 AUSTENITIC MATERIALS}

All evidence available to date indicates that stable austenitic stainless steels possess excellent resistance to irradiation damage up to an integrated fast neutron flux of at least 1-2 $\times 10^{21}$ nvt. Both post-irradiation impact testing, although limited in scope, and low temperature impact testing show no evidence of brittle characteristics in this type of material. 
Normal mechanical property test data summarized in Appendix Tables 6 and 7 show decreases in ductility properties and increases in strength properties for austenitic stainless steels after irradiation. The decreases in ductility and increases in strength, however, are only a fraction of the changes representative of ferritic steels.

Unirradiated austenitic stainless steels, being single-phase alloys, are hardenable only by cold work. Except in a severely cold worked condition, as-fabricated ductilities considerably in excess of ferritic steels are exhibited. (28) Similar high ductilities are observed for annealed and mildly cold worked austenitic materials even after irradiation at high neutron fluxes. Type 347, for example, after an exposure of $3.7 \times 10^{21}$ nvt, retained an elongation of $32 \%$ from a pre-irradiation value of about $60 \%$, with a negligible decrease in reduction in area. This is the highest irradiation exposure reported for any material tested to date. The post-irradiated ductility of this material, as judged by elongation and reduction in area, is at least as good or better than ferritic materials in the as-fabricated condition.

Based on available data and experience, there is no indication of the possibility of brittle failure due to irradiation of austenitic stainless steels at the maximum integrated flux considered for the SM-2 reactor vessel. Although the majority of irradiation data published to date has been on Type 347 stainless steel, the data available for Type 304, as shown in Appendix Table 6, indicates comparable performance.

Since problems associated with the fabrication of thick sections of Type $\mathbf{3 4 7}$ stainless steel can be severe, Type 304 is preferred from the standpoint of producing a reactor vessel of highest quality. Possible weld cracking difficulties anticipated with the fabrication of a heavy walled Type 347 vessel will be eliminated by the use of Type 304 as the material of construction. 


\section{O SERVICE PERFORMANCE}

In the study of irradiation damage phenomena, as in other fields, an actual operating test is the final proof of prediction of satisfactory performance. Sample testing, although providing basic data necessary for full understanding of any materials problem, usually cannot simulate environment, stress and stress concentrations, rate of loading, and other factors characteristic of an operating vessel. Prediction of performance based on only relatively small size sample testing is always subject to question. The desirability of proof testing under service conditions cannot be over-emphasized.

Fortunately, some data on the effects of neutron irradiation upon structural materials in actual reactor operation after exposure to fluxes as high as $3 \times 10^{20}$ nvt are available. (29) Tests have been made on samples taken from both ferritic and stainless steel in-pile water loops used in the Material Test Reactor (MTR) at nominal water temperatures of $600^{\circ} \mathrm{F}$ and working pressures as high as $2050 \mathrm{psi}$. Although functioning to test irradiation stability of fuel assemblies, the loops themselves constitute the best test to date of the performance of high pressure, high temperature piping and pressure vessels in very high flux regions.

Sections of both a Type 304 stainless steel loop and an ASTM A-201B carbon steel loop were removed for testing and examination after an exposure of $3 \times 10^{20}$ nvt. Type 304 stainless steel loop samples could be bent through $180^{\circ}$ and then crushed flat upon themselves without cracking. A ring section of ASTM A-201B carbon steel which had been exposed to the same nvt failed in a brittle manner when flattened from its original diameter of 4 inches to a diameter of only 3-3/4 inches. Cracking did not occur, however, in crush rings cut from ASTM A-201B carbon steel loop sections which had been exposed to a lower integrated flux of $4 \times 10^{19}$ nvt. These rings could be flattened without failure in exactly the same manner as the stainless steel rings.

These tests, although not qualitative in nature, dramatically illustrate not only the severe embrittling effects of excessive irradiation upon ferritic materials, but also the ability of stable austenitic stainless steel to resist serious degradation of material properties. At the same time, these tests highlight the ability of carbon steels to withstand an integrated flux of $4 \times 10^{19}$ nvt under conditions of operation which are similar to SM-2 operating conditions.

Mechanical property tests performed on sections of the carbon steel loop after exposure to $4 \times 10^{19}$ nvt are shown in Appendix Table 8. Both 
strength and ductility changes are considerably less than would be expected for this integrated neutron flux on the basis of previous tests performed on specimens irradiated at much lower temperatures. It must be concluded that the combination of high flux rate, stress under operation and elevated temperature of operation provided a beneficial effect in reducing irradiation damage. Based on these tests, complete confidence would be expressed for performance of a ferritic pressure vessel under similar conditions.

Both ASTM A-201B and ASTM A-21 2B are silicon-killed carbon steels differing slightly in carbon and manganese contents. The SM-2 reactor vessel wall temperature is about $550^{\circ} \mathrm{F}$, which is oniy slightly lower than the MTR loop temperature. The similarity in materials of construction and in operating conditions of recommended SM-2 reactor vessels to the MTR loop materials and operating conditions confirms the validity of selection of ASTM A-212B carbon steel and Type 304 stainless steel at limiting flux values of 4-5 x $10^{19}$ nvt and $1 \times 10^{21}$ nvt respectively. 


\section{0 CONCLUSIONS}

Evaluation of the irradiation data obtained on the various ferritic steels and austenitic stainless steels studied in this literature survey revealed that either stainless clad ASTM A-212B carbon steel or Type 304 stainless steel can be used for the SM-2 reactor vessel, depending on the vessel size. These materials were evaluated on the basis of reported increases in transition temperature, decreases in maximum energy absorption, susceptibility to temper embrittlement, and actual service experience.

Austenitic stainless steels such as Type 304 or Type 347 are believed to be capable of resisting harmful property damage at integrated neutron fluxes $>1$ Mev of at least $1-2 \times 10^{21}$ nvt. Calculated 20 year "nvt" values for various SM-2 reactor vessel designs indicate that a 41" I. D. vessel would be satisfactory at this exposure level. Aithough both Type 304 and Type 347 appear to possess equivalent resistance to irradiation damage, Type 304 is preferable as a reactor vessel material for the SM-2 since fabrication and welding difficulties normally associated with heavy sections of Type $\mathbf{3 4 7}$ are not characteristic of this grade of steel.

ASTM A-212B carbon silicon steel, on the other hand, is capable of resisting severe property damage at integrated neutron fluxes $>1 \mathrm{Mev}$ of $4-5 \times 10^{19}$ nvt, provided special precautionary startup and shutdown procedures are employed. Such precautionary measures are essential in order to prevent application of significant loading at temperatures less than $185^{\circ} \mathrm{F}$. Specification of this minimum startup temperature and of application of ASTM A-300 to the base metal, weld metal, and heat affected zones would be necessary.

Other ferritic materials were disqualified in the overall evaluation due to excessive irradiation induced property changes or because of the lack of industrial experience.

Satisfactory service perfor mance of an SM-2 reactor vessel constructed of either Type 304 stainless steel or ASTM A-212B carbon steel depending on vessel size, is further assured by the favorable data obtained from recent MTR tests on almost identical materials of construction and under flux and temperature conditions quite similar to those anticipated in the SM-2.

Since nuclear and mechanical design considerations indicate that a small sized vessel would be highly desirable, Type 304 stainless steel is recommended as the reference reactor vessel material for the SM-2. 


\section{O REFERENCES}

1. D. O. Lesser, "Radiation Effects on Welds and Notches in Plain Carbon Steels, Stainless Steels, and Non-Ferrous Alloys," ASTM Special Technical Publication No. 208, 1957, p. 154.

2. J. C. Wilson and R. G. Berggren, "Effect of Neutron Irradiation in Steel, " ASTM Proc. Vol. 55, p. 691.

3. D. R. Harries, "A Survey of the Effect of Neutron Irradiation on the Properties of Iron and Steels," AERE-M/TN-54,pp. 2, 30.

4. American Society for Testing Materials, "Tentative Specifications for High Tensile Strength Carbon - Silicon Steel Plates for Boilèrs and Other Pressure Vessels, (A-212-54a T), " 1955 Book of ASTM Siandards, Part I, p. 501.

5. B. E. Fried, "Calculated 20 Year "NVT" Values for Various SM-2 Reactor Vessel Designs vs. Inside Diameter of Vessel, " APAE Memo 197, sM-2 Reactor Core and Vessel Review Report, February' 14, 1959 to May 27, 1959.

6. B. C. Allen, A. K. Wolff, A.R. Elsea, and P.D. Frost, "The Effect of Nuclear Irradiation on Structural Metals, "REIC Report No. 5, May 31, 1958,pp. 2, 3, 7.

7. J. C. Wilson and D. S. Billington, "Effect of Neutron Irradiation on Structural Materials," ORNL Preprint 01, p. 5.

8. M. E. Shank, "Control of Steel Construction to Avoid Brittle Failure," Prepared by Plasticity Committee of the Welding Research Councll, p. 117.

9. T. N. Armstrong, N. A. Kahn, and Helmut Thielsch, "Transition from Ductile to Brittle Behavior in Pressure Vessel Steels, " August 1952 Welding Journal Research Supplement.

10. P. P. Puzak, A. J. Babecki, and W. S. Pellini, "Correlations of Brittle Fracture Service Failures with Laboratory Notch Ductility Tests," September 1958, Welding Journal Research Supplement.

11. J. C. Wilson and R. G. Berggren, "Recent Data on the Effects of Neutron Irradiation on Structural Metals and Alloys, " ORNL -CF-56-11-1, January 30, 1957. 
12. 8. L. Hoyt, "Brittle Fracture," AsTM Special Technical Publication No. 158, June 1953, p. 137.

13. P. P. Puzak and W. S. Pellini, "Evaluation of the Significance of Charpy Tests for Quenched and Tempered Steels, June 1956 Welding Journal Research Supplement.

14. Bureau of Ships, "Tentative Structural Design Basis for Reactor Pressure Vessels and Directly Associated Components," December 1, 1958, Ref. BuShips Itr SSN/s 51 (551B) Ser: 551B-596 dated 1 April 1958.

15. J. R. Hawthorne and L. E. Steel, "The Effect of Neutron Irradiation on the Charpy "V" and Drop Weight Test Transition Temperatures of Various steels and Weld Metals," U. S. Naval Research Laboratory, Washington 25, D. C.

16. J. C. Wilson, "Effects of Irradiation on the Structural Materials in Nuclear Power Reactors," A/Conf. 15/P/1978, June 1958.

17. N. Balai, "Reactor Pressure Vessel Design for Nuclear Applications," ASTM Special Technical Publication No. 233, Volume 3, p. 63 - 83.

18. L. E. Steele and J. R. Hawthorne, U. S. Naval Research Laboratory, Washington, 25, D. C. , Telephone Conversation with R. W. Kelleman, Alco Products, Inc. , Schenectady, New York, Nov. 1959.

19. L. P. Trudeau, "Effect of Neutron Irradiation on the Mechanical Properties of Ferritic Steels," UK/C/6/108, Chalk River, Ontario, September 1957.

20. G. M. Adamson, "Effects of Radiation on Structural Metals and Alloys," ORNL-2561, Homogeneous Reactor Project Quarterly Progress Report for Periods Ending April 30 and July 31, 1958, p. 258 - 264.

21. L. P. Trudeau, " Effect of Irradiation on the Mechanical Properties of Materials for Reactor Pressures Vessels," presented at AEC Conference, Chicago, Illinois, October 15-16, 1958.

22. T. N. Armstrong, J. H. Gross, and R. E. Brien, International Nickel Company, New York, N. X. , "Properties Affecting Suitability of $9 \%$ Nickel Steel for Low Temperature Service," Welding Journal Research Supplement February 1959.

23. R. J. Johnson, International Nickel Company, Telephone Conversation with R. W. Kelleman, Alco Products, Inc. , Schenectady N. Y., May 8, 1959. 
24. Welding Research Council, "Minutes of Meeting of Pressure Vessel Research Committee," November 1959, p. 24-31.

25. L. P. Trudeau, International Nickel Company of Canada Limited, Chalk River, Ontario, Personal Correspondence with R. W. Kelleman, Alco Products, Inc., Schenectady, N. Y.

26. G. M. Adamson, "Effects of Radiation on Structural Metals and Alloys," ORNL-2654, Homogeneous Reactor Project Quarterly Progress Report for Period Ending October 31, 1958, p. 192.

27. W. S. Pellini, "Notch Ductility of Weid Metal", May 1956 Welding Journal Research Supplement.

28. Studies of Seven Non-Fissionable Metals, " Nuclear Engineering and Science Conference in Chicago, March 17-21, 1958.

29. M. H. Bartz, "Performance of Metals During Six Years Service in the Materials Testing Reactor," A/Conf/15/P/1878, June 1958.

30. M. L. Bleiber, "Effect of Neutron Bombardment Upon the Properties of ASTM A-212B Steel," WAPD T-206, October 12, 1955.

31. E. E. Baldwin, "The Effects of Temperature and Irradiation Upon the Tenisile and Impact Properties of ASTM A-302B Manganese-Molybdenum Steel," KAPL-1416, October 1, 1955.

32. L. P. Trudeau, "Effects of Neutron Irradiation on the Mechanical Properties of Ferritic Steels and Irons, " A/Conf/15/P/190, September 1958.

33. R. L. Mehan and E. E. Baldwin, "Effect of Neutron Irradiation on Notched Bend and Tensile Properties of ASTM A-201 A Carbon Steel," KAPL-1874, November 9, 1957.

34. J. C. Wilson and R. G. Berggren, "HRP Radiation Metallurgy," ORNL2614, Solid State Division Annual Progress Report For Period Ending August 31, 1958, p. 98-103.

35. R. J. Johnson, International Nickel Company, Letter dated May 13, 1959 to R. W. Kelleman, Alco Products, Inc., Schenectady, N. Y.

36. R. D. Stout, Lehigh University Bethlehem, Pa. Telephone Conversation with R. W. Kelleman, Alco Products, Inc. , Schenectady, N. Y. , May 18, 1959.

37. Welding Research Council, "Minutes of Meeting of Pressure Vessel Research Committee," October 1958. 
38. W. C. Thurber and J. T. Lamartine, Determination of the NilDuctility-Transition Temperature for ASTM A-212B Steel used in the N. S. Savannah Pressure Vessel, ORNL-CF-59-7-143, July 23, 1959. 


\section{1 APPENDIX TABLES}

\section{LIST OF APPENDIX TABLES}

Table

Title

Transition Temperature and Energy Absorption

Data for Irradiated and Unirradiated Carbon

and Low Alloy Steels ....................

2 Chemical Composition of Various Carbon, Low Alloy and Stainless Steel Structural Materials _. . . . . . 46

3 Pre- and Post-Irradiation Tensile Properties of Various Carbon and Low Alloy Steels...........

Erfect of Long Exposure at $700^{\circ} \mathrm{F}$ on the Charpy "V" Notch 15-mil Transition Temperature of ASTM A-353 (9\% Nickel Steel) _................

Effect of Long Exposure at $500^{\circ} \mathrm{F}$ and $700^{\circ} \mathrm{F}$ on the Charpy "V" Notch 15 mil Transition Temperature of ASTM A-203 Grade D (3-1/2\% Nickel Steel)

Effects of Neutron Ir radiation on the Room Temperature Tensile Properties of Annealed and Irradiated Austenitic Stainless Steels ..................

Effects of High Neutron Doses on the Room Temperature Tensile Properties of Type 347 Stainless

Steel .................................

Mechanical Properties of ASTM A-201 Grade B Carbon Steel Before and After Exposure to $410^{19}$ NVT in the MTR 
TABLE 1 (CONT'D)

\begin{tabular}{|c|c|c|c|c|c|c|c|c|}
\hline Material & Condition & $\begin{array}{l}\text { NVT } \\
\text { Integrated } \\
\text { Flux }>1 \text { Mev } \\
\end{array}$ & $\begin{array}{l}\text { Irrad. } \\
\text { Temp. }\end{array}$ & $\begin{array}{l}\text { Mid-Range } \\
\text { Trans. Temp. }\end{array}$ & $\begin{array}{l}\text { Increase in } \\
\text { Trans. Temp. }\end{array}$ & $\begin{array}{l}\text { Maximum Abs. } \\
\text { Energy Ft. lbs. }\end{array}$ & $\begin{array}{l}\text { \% Decrease } \\
\text { in Max. Abs. } \\
\text { Energy }\end{array}$ & Source of Data \\
\hline ASTM A-212B & $\begin{array}{l}\text { N } 1650^{\circ} \mathrm{F} \text { and } \\
\text { SR } 1175^{\circ} \mathrm{F}\end{array}$ & 0 & $\cdots$ & $\cdots$ & $\cdots$ & 7.2 & -.. & WAPD-T-206 \\
\hline ASTM A-212B & $\begin{array}{l}\mathrm{N} 1650^{\circ} \mathrm{F} \text { and } \\
\mathrm{SR} 1175^{\circ} \mathrm{F}\end{array}$ & $3 \times 10^{19}$ & $200^{\circ} \mathrm{F}$ & $239^{\circ} \mathrm{F}$ & $189^{\circ} \mathrm{F}$ & 4.5 & 38 & WAPD-T-206 \\
\hline ASTM A-212B & N $1650^{\circ} \mathrm{F}$ and & $3 \times 10^{19}$ & $200^{\circ} \mathrm{F}$ & $275^{\circ} \mathrm{F}$ & $225^{\circ} \mathrm{F}$ & 4.5 & 38 & WAPD-T-206 \\
\hline ASTM A-212B & $\begin{array}{l}\mathrm{N} 1650^{\circ} \mathrm{F} \text { and } \\
\mathrm{SR} 1175^{\circ} \mathrm{F}\end{array}$ & $1.5 \times 10^{20}$ & $200^{\circ} \mathrm{F}$ & $320^{\circ} \mathrm{F}$ & $270^{\circ} \mathrm{F}$ & 4.5 & 38 & WAPD-T-206 \\
\hline ASTM A-212B & $\begin{array}{l}\text { N } 1650^{\circ} \mathrm{F} \text { and } \\
\mathrm{SR}^{\prime} 1175^{\circ} \mathrm{F}\end{array}$ & $2.1 \times 10^{20}$ & $200^{\circ} \mathrm{F}$ & $338^{\circ} \mathrm{F}$ & $288^{\circ} \mathrm{F}$ & 3.8 & 47 & WAPD-T-206 \\
\hline ASTM A-212B & Made to & 0 & $\cdots$ & $15^{\circ} \mathrm{F}$ & $\cdots$ & 6.7 & -.. & ORNL-CF-56-11-1 \\
\hline ASTM A-212B & Made to & $5 \times 10^{18}$ & $200^{\circ} \mathrm{F}$ & $60^{\circ} \mathrm{F}$ & $45^{\circ} \mathrm{F}$ & 5.8 & 8 & ORNL-CF-56-11-1 \\
\hline $\begin{array}{l}\text { (Base Plate) } \\
\text { ASTM A-212B }\end{array}$ & Made to & $5 \times 10^{18}$ & $600^{\circ} \mathrm{F}$ & ${ }_{25}^{\circ} \mathrm{F}$ & $10^{\circ} \mathrm{F}$ & 7.0 & $11 \%^{c}$ & ORNL-CF-56-11-1 \\
\hline $\begin{array}{l}\text { (Base Plate) } \\
\text { ASTM A-212B }\end{array}$ & $\begin{array}{l}\text { SA-300 Spec. } \\
\text { Made to }\end{array}$ & $5 \times 10^{19}$ & $200^{\circ} \mathrm{F}$ & $250^{\circ} \mathrm{F}$ & $235^{\circ} \mathrm{F}$ & 3.6 & 43 & ORNL-CF-56-11-1 \\
\hline $\begin{array}{l}\text { ASTM A-212B } \\
\text { (Base Plate) }\end{array}$ & $\begin{array}{l}\text { Made to } \\
\text { SA-300 Spec. }\end{array}$ & $1.3 \times 10^{20}$ & $200^{\circ} \mathrm{F}$ & $275^{\circ} \mathrm{F}$ & $260^{\circ} \mathrm{F}$ & 3.0 & 53 & ORNL-CF-56-11-1 \\
\hline $\begin{array}{l}\text { ASTM A-212B } \\
\text { HAZ }\end{array}$ & $\begin{array}{l}\text { Made to } \\
\text { SA-300 Spec. }\end{array}$ & 0 & ... & $-40^{\circ} \mathrm{F}$ & ... & 10.9 & -.. & ORNL-CF-56-11-1 \\
\hline $\begin{array}{l}\text { ASTM A-212B } \\
\text { HAZ }\end{array}$ & $\begin{array}{l}\text { Made to } \\
\text { SA-300 Spec. }\end{array}$ & $7.6 \times 10^{19}$ & $200^{\circ} \mathrm{F}$ & $260^{\circ} \mathrm{F}$ & $300^{\circ} \mathrm{F}$ & 4.3 & 60 & ORNL-CF-56-11-1 \\
\hline ASTM A-212B & $\mathrm{N}$ and SR & $5 \times 10^{19}$ & $200^{\circ} \mathrm{F}$ & $\cdots$ & $220^{\circ} \mathrm{F}$ & $\cdots$ & 30 & Geneva Paper 1978 \\
\hline $\begin{array}{l}\text { ASTM A-212B } \\
\text { HAZ }\end{array}$ & $\mathrm{N}$ and $\mathrm{SR}$ & $8 \times 10^{19}$ & $200^{\circ} \mathrm{F}$ & $\cdots$ & $350^{\circ} \mathrm{F}$ & ... & 60 & Geneva Paper 1978 \\
\hline $\begin{array}{l}\text { E-7016 Carbon } \\
\text { Steel Weld Metal }\end{array}$ & No Ht. Tr. & 0 & $\cdots$ & $-50^{\circ} \mathrm{F}$ & $\cdots$ & 12.6 & $\cdots$ & ORNL-CF-56-11-1 \\
\hline $\begin{array}{l}\text { E-7016 Carbon } \\
\text { Steel Weld Metal }\end{array}$ & No Ht. Tr. & $1.2 \times 10^{19}$ & $200^{\circ} \mathrm{F}$ & $125^{\circ} \mathrm{F}$ & $175^{\circ} \mathrm{F}$ & 7.5 & 40 & ORNL-CF-56-11-1 \\
\hline E-7016 Carbon & No Ht. Tr. & $1.7 \times 10^{19}$ & $200^{\circ} \mathrm{F}$ & $150^{\circ} \mathrm{F}$ & $200^{\circ} \mathrm{F}$ & 7.0 & 45 & ORNL-CF-56-11-1 \\
\hline E-7016 Carbon & No Ht. Tr. & $1.2 \times 10^{20}$ & $200^{\circ} \mathrm{F}$ & $250^{\circ} \mathrm{F}$ & $300^{\circ} \mathrm{F}$ & 6.0 & 52 & ORNL-CF-56-11-1 \\
\hline E-7016 Carbon & $\mathrm{SR}, \mathrm{Q} \& \mathrm{~T}$ & $2.0 \times 10^{19}$ & $200^{\circ} \mathrm{F}$ & $\cdots$ & $210^{\circ} \mathrm{F}$ & $\cdots$ & 40 & Geneva Paper 1978 \\
\hline E-7016 Carbon & SR, Q \& T & $8.0 \times 10^{19}$ & $2000 \mathrm{~F}$ & -.. & $360^{\circ} \mathrm{F}$ & $\cdots$ & 55 & Geneva Paper 1978 \\
\hline
\end{tabular}


TABLE 1 (CONTD)

\begin{tabular}{|c|c|c|c|c|c|c|c|c|}
\hline Material & Condition & $\begin{array}{l}\text { NVT } \\
\text { Integrated } \\
\text { Flux }>1 \text { Mev } \\
\end{array}$ & $\begin{array}{l}\text { Irrad. } \\
\text { Temp. }\end{array}$ & $\begin{array}{l}\text { Mid-Range } \\
\text { Trans. Temp. }\end{array}$ & $\begin{array}{l}\text { Increase in } \\
\text { Trans. Temp. }\end{array}$ & $\begin{array}{l}\text { Maximum Abs. } \\
\text { Energy Ft. lbs. }\end{array}$ & $\begin{array}{l}\text { \% Decrease } \\
\text { in Max. Abs. } \\
\text { Energy }\end{array}$ & Source of Data \\
\hline E-7016 Carbon & 4" Multipass & 0 & $\ldots$ & $-60^{\circ} \mathrm{F}$ & -.. & 13 & $\ldots$ & ORNL-2561 \\
\hline $\begin{array}{l}\text { Steel Weld Metal } \\
\text { E-7016 Carbon }\end{array}$ & $\begin{array}{l}\text { Butt Weld } \\
\text { 4" Multipass }\end{array}$ & $1.6 \times 10^{19}$ & $440^{\circ} \mathrm{F}$ & $75^{\circ} \mathrm{F}$ & $135^{\circ} \mathrm{F}$ & $-\cdot$ & $\cdots$ & ORNL-2561 \\
\hline $\begin{array}{l}\text { Steel Weld Metal } \\
\text { E-7016 Carbon }\end{array}$ & $\begin{array}{l}\text { Butt Weld } \\
\text { 4" Multipass }\end{array}$ & $1.6 \times 10^{19}$ & $500^{\circ} \mathrm{F}$ & $25^{\circ} \mathrm{F}$ & $85^{\circ} \mathrm{F}$ & $\cdots$ & $\cdots$ & ORNL-2561 \\
\hline $\begin{array}{l}\text { Steel Weld Metal } \\
\text { E-7016 Carbon }\end{array}$ & $\begin{array}{l}\text { Butt Weld } \\
4^{*} \text { Multipass }\end{array}$ & $1.6 \times 10^{19}$ & $540^{\circ} \mathrm{F}$ & $60^{\circ} \mathrm{F}$ & $120^{\circ} \mathrm{F}$ & $\cdots$ & $\cdots$ & ORNL-2561 \\
\hline $\begin{array}{l}\text { Steel Weld Metal } \\
\text { E-7016 Carbon }\end{array}$ & $\begin{array}{l}\text { Butt Wuld } \\
\text { 4" Multipass }^{2}\end{array}$ & $1.7 \times 10^{19}$ & $175^{\circ} \mathrm{F}$ & $150^{\circ} \mathrm{F}$ & $210^{\circ} \mathrm{F}$ & $\cdots$ & $\cdots$ & ORNL-2561 \\
\hline $\begin{array}{l}\text { Steel Weld Metal } \\
\text { E-7016 Carbon }\end{array}$ & $\begin{array}{l}\text { Butt Weld } \\
\text { ४ Multipass }^{*} \text { Mula }\end{array}$ & $2.3 \times 10^{19}$ & $500^{\circ} \mathrm{F}$ & $100^{\circ} \mathrm{F}$ & $160^{\circ} \mathrm{F}$ & $-\cdot$ & - & ORNL-2561 \\
\hline $\begin{array}{l}\text { Steel Weld Metal } \\
\text { E-7016 Carbon }\end{array}$ & $\begin{array}{l}\text { Butt Weid } \\
\text { 4" Multipass }^{\prime \prime}\end{array}$ & $2.3 \times 10^{19}$ & $540^{\circ} \mathrm{F}$ & $75^{\circ} \mathrm{F}$ & $135^{\circ} \mathrm{F}$ & $\cdots$ & -.. & ORNL-2561 \\
\hline $\begin{array}{l}\text { Steel Weld Metal } \\
\text { E-7016 Carbon }\end{array}$ & $\begin{array}{l}\text { Butt Weld } \\
\text { 4" Multipass }\end{array}$ & $2.3 \times 10^{19}$ & $560^{\circ} \mathrm{F}$ & $50^{\circ} \mathrm{F}$ & $110^{\circ} \mathrm{F}$ & $\cdots$ & $\cdots$ & ORNL-2561 \\
\hline $\begin{array}{l}\text { Steel Weld Metal } \\
\text { E-7016 Carbon }\end{array}$ & $\begin{array}{l}\text { Butt Weld } \\
\text { 4" Multipass }^{\text {" M }}\end{array}$ & $7 \times 10^{19}$ & $560^{\circ} \mathrm{F}$ & $60^{\circ} \mathrm{F}$ & $120^{\circ} \mathrm{F}$ & $\cdots$ & $\ldots$ & ORNL-2561 \\
\hline $\begin{array}{l}\text { Steel Weld Metal } \\
\text { E-7016 Carbon }\end{array}$ & $\begin{array}{l}\text { Butt Weld } \\
\text { 4" Multipass }^{\prime \prime}\end{array}$ & $7 \times 10^{19}$ & $580^{\circ} \mathrm{F}$ & $50^{\circ} \mathrm{F}$ & $110^{\circ} \mathrm{F}$ & $\cdots$ & $\cdots$ & ORNL-2561 \\
\hline $\begin{array}{l}\text { Steel Weld Metal } \\
\text { E-7016 Carbon }\end{array}$ & $\begin{array}{l}\text { Butt Weld } \\
\text { 4" Multipass }\end{array}$ & $7 \times 10^{19}$ & $600^{\circ} \mathrm{F}$ & $25^{\circ} \mathrm{F}$ & $85^{\circ} \mathrm{F}$ & $\cdots$ & $\cdots$ & ORNL-2561 \\
\hline E-7016 Carbon & 4" Multipass & $1.2 \times 10^{20}$ & $175^{\circ} \mathrm{F}$ & $250^{\circ} \mathrm{F}$ & $310^{\circ} \mathrm{F}$ & $\cdots$ & $-\cdot$ & ORNL-2561 \\
\hline $\begin{array}{l}\text { Steel Weld Metal } \\
\text { E-7016 Carbon } \\
\text { Steel Weld Metal }\end{array}$ & $\begin{array}{l}\text { Butt Weld } \\
\text { 4"'Multipass } \\
\text { Butt Weld }\end{array}$ & $1.2 \times 10^{20}$ & $600^{\circ} \mathrm{F}$ & $75^{\circ} \mathrm{F}$ & $135^{\circ} \mathrm{F}$ & $\cdots$ & $\cdots$ & ORNL-2561 \\
\hline ASTM A-212B & $\mathrm{HR}^{*}$ & 0 & $\cdots$ & $-75^{\circ} F$ & & 35 & $\cdots$ & ORNL-2561 \\
\hline ASTM A-212B & $\mathrm{HR}^{*}$ & $1 \times 10^{18}$ & $175^{\circ} \mathrm{F}$ & $25^{\circ} \mathrm{F}$ & $50^{\circ} \mathrm{F}$ & 31 & 12 & ORNL-2561 \\
\hline ASTM A-212B & $\mathrm{HR}^{*}$ & $5 \times 10^{18}$ & $175^{\circ} \mathrm{F}$ & $25^{\circ} \mathrm{F}$ & $100^{\circ} \mathrm{F}$ & 27 & 23 & ORNL-2561 \\
\hline ASTM A-212B & $\mathrm{HR}^{*}$ & $5 \times 10^{18}$ & $575^{\circ} \mathrm{F}$ & $-35^{\circ} \mathbf{F}$ & $40^{\circ} \mathrm{F}$ & 31 & 12 & ORNL-2561 \\
\hline ASTM A-212B & $\mathbf{N}^{*}$ & $0 \quad 18$ & $=-$ & $-35^{\circ} \mathbf{F}$ & 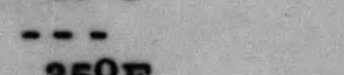 & 38 & $=-$ & ORNL-2561 \\
\hline ASTM A-212B & $\mathbf{N}^{*}$ & $1 \times 10_{18}^{18}$ & $175^{\circ} \mathrm{F}$ & $0^{\circ} \mathbf{F}$ & $35^{\circ} \mathrm{F}$ & 34 & 10 & ORNL-2561 \\
\hline ASTM A-212B & $\mathbf{N}^{*}$ & $5 \times 10^{18}$ & $175^{\circ} \mathrm{F}$ & $65^{\circ} \mathrm{F}$ & $100^{\circ} \mathrm{F}$ & 33 & 13 & ORNL-2561 \\
\hline ASTM A-212B & $\mathrm{N}^{*}$ & $5 \times 10^{18}$ & $575^{\circ} \mathrm{F}$ & $-25^{\circ} \mathrm{F}$ & $10^{\circ} \mathrm{F}$ & 35 & 8 & ORNL-2561 \\
\hline ASTM A-212B & $N \& \mathrm{SR}^{*}$ & & & $50^{\circ} \mathrm{F}$ & & 92 & -.. & ORNL-2561 \\
\hline ASTM A-212B & $N \& \mathrm{SR}^{*}$ & $5 \times 10^{18}$ & $175^{\circ} \mathrm{F}$ & $175^{\circ} \mathrm{F}$ & $125^{\circ} \mathrm{F}$ & 82 & 11 & ORNL-2561 \\
\hline ASTM A-212B & $\mathrm{N} \& \mathrm{SR}^{*}$ & $5 \times 10^{18}$ & $575^{\circ} \mathrm{F}$ & $175^{\circ} \mathrm{F}$ & $125^{\circ} \mathrm{F}$ & 82 & 11 & ORNL-2561 \\
\hline
\end{tabular}


TABLE 1 (CONTD)

\begin{tabular}{|c|c|c|c|c|c|c|c|c|}
\hline Material & Condition & $\begin{array}{l}\text { NVT } \\
\text { Integrated } \\
\text { Flux }>1 \text { Mev } \\
\end{array}$ & $\begin{array}{l}\text { Irrad. } \\
\text { Temp. }\end{array}$ & $\begin{array}{l}\text { Mid-Range } \\
\text { Trans. Temp. }\end{array}$ & $\begin{array}{l}\text { Increase in } \\
\text { Trans. Temp. }\end{array}$ & $\begin{array}{l}\text { Maximum Abs. } \\
\text { Energy Ft. lbs. }\end{array}$ & $\begin{array}{l}\text { \%Decrease } \\
\text { in Max. Abs. } \\
\text { Energy } \\
\end{array}$ & Source of Data \\
\hline ASTM A-106A & N $1700^{\circ} \mathrm{F}$ & 0 & $\cdots$ & $-35^{\circ} F$ & $\cdots$ & 8.3 & $\ldots$ & ORNL-CF-56-11-1 \\
\hline $\begin{array}{l}\text { (Fine Grained) } \\
\text { ASTM A-106A }\end{array}$ & $N 1700^{\circ} \mathrm{F}$ & $5 \times 10^{18}$ & $200^{\circ} \mathrm{F}$ & $35^{\circ} \mathrm{F}$ & $70^{\circ} \mathrm{F}$ & 11.0 & $25^{c}$ & ORNL-CF-56-11-1 \\
\hline ASTM A-106A & $\mathrm{N} 1700^{\circ} \mathrm{F}$ & $5 \times 10^{18}$ & $600^{\circ} \mathrm{F}$ & $-10^{\circ} F$ & $25^{\circ} \mathrm{F}$ & 10.4 & $20^{c}$ & ORNL-CF-56-11-1 \\
\hline ASTM A-106A & $\mathrm{N} 1700^{\circ} \mathrm{F}$ & $5 \times 10^{19}$ & $200^{\circ} \mathrm{F}$ & -- & $85^{\circ} \mathrm{F}$ & $\cdots$ & 0 & Geneva Paper 1978 \\
\hline $\begin{array}{l}\text { (Fine Grained) } \\
\text { ASTM A-106A }\end{array}$ & $N 1700^{\circ} \mathrm{F}$ & $8 \times 10^{19}$ & $200^{\circ} \mathrm{F}$ & -- & $250^{\circ} \mathrm{F}$ & $\cdots$ & 30 & Geneva Paper 1978 \\
\hline ASTM A-106A & $N 1700^{\circ} \mathrm{F}$ & $1 \times 10^{20}$ & $200^{\circ} \mathrm{F}$ & $175^{\circ} \mathrm{F}$ & $210^{\circ} \mathrm{F}$ & 5.0 & 40 & ORNL-CF-56-11-1 \\
\hline ASTM A-106A & $N 1700^{\circ} \mathrm{F}$ & 0 & $\cdots$ & $50^{\circ} \mathrm{F}$ & $\cdots$ & 9.0 & $\cdots$ & ORNL-CF-56-11-1 \\
\hline (Coarse Grained) & $\mathrm{N} 1700^{\circ} \mathrm{F}$ & $5 \times 10^{18}$ & $200^{\circ} \mathrm{F}$ & $75^{\circ} \mathrm{F}$ & $25^{\circ} \mathrm{F}$. & 7.5 & 17 & ORNL-CF-56-11-1 \\
\hline ASTM A-106A & N $1700^{\circ} \mathrm{F}$ & $5 \times 10^{18}$ & $600^{\circ} \mathrm{F}$ & $70^{\circ} \mathrm{F}$ & $20^{\circ} \mathrm{F}$ & 8.0 & 11 & ORNL-CF-56-11-1 \\
\hline ASTM A-106A & $N 1700^{\circ} \mathrm{F}$ & $5 \times 10^{19}$ & $200^{\circ} \mathrm{F}$ & $\cdots$ & $30^{\circ} \mathrm{F}$ & $\cdots$ & $\cdots$ & Geneva Paper 1978 \\
\hline ASTM A-106A & $N 1700^{\circ} \mathrm{F}$ & $8 \times 10^{19}$ & $200^{\circ} \mathrm{F}$ & 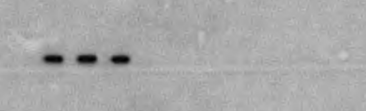 & $300^{\circ} \mathrm{F}$ & $\cdots$ & 55 & Geneva Paper 1978 \\
\hline $\begin{array}{l}\text { ASTM A-106A } \\
\text { (Coarse Grained) }\end{array}$ & $N 1700^{\circ} \mathrm{F}$ & $1 \times 10^{20}$ & $200^{\circ} \mathrm{F}$ & $300^{\circ} \mathrm{F}$ & $350^{\circ} \mathrm{F}$ & 4.5 & 50 & ORNL-CF-56-11-1 \\
\hline $\begin{array}{l}\text { ASTM A-285A } \\
\text { ASTM A-285A }\end{array}$ & $\begin{array}{l}\text { HRR } \\
\text { HR }\end{array}$ & $\begin{array}{l}0 \\
5 \times 10^{18}\end{array}$ & $200^{\circ} \mathrm{F}$ & $\begin{array}{l}25^{\circ} \mathrm{F} \\
70^{\circ} \mathrm{F}\end{array}$ & $45^{\circ} \mathrm{F}$ & $\begin{array}{l}7.0 \\
6.2\end{array}$ & 12 & $\begin{array}{l}\text { ORNL-CF-56-11-1 } \\
\text { ORNL-CF-56-11-1 }\end{array}$ \\
\hline ASTM A-285A & HR* & & $\cdots$ & $75^{\circ} \bar{F}$ & $\cdots$ & 77 & $\cdots$ & ORNL-2561 \\
\hline ASTM A-285A & HR* & $1 \times 10^{18}$ & $200^{\circ} \mathrm{F}$ & $175^{\circ} \mathrm{F}$ & $100^{\circ} \mathrm{F}$ & 72 & 6.5 & ORNL-2561 \\
\hline ASTM A-285A & HR* & $5 \times 10_{18}^{18}$ & $200^{\circ} \mathrm{F}$ & $250^{\circ} \mathrm{F}$ & $175^{\circ} \mathrm{F}$ & 65 & 16 & ORNL-2561 \\
\hline ASTM A-285A & HR* & $5 \times 10^{18}$ & $575^{\circ} \mathrm{F}$ & $150 \mathrm{~F}$ & $75^{\circ} \mathrm{F}$ & $\cdots$ & $\cdots$ & ORNL-2561 \\
\hline ASTM A-285A & $\mathbf{N}^{*}$ & & $\cdots$ & $65^{\circ} \mathrm{F}$ & $\cdots$ & 79 & $\cdots$ & ORNL-2561 \\
\hline ASTM A-285A & $\mathbf{N}^{*}$ & $1 \times 10_{18}^{18}$ & $200^{\circ} \mathrm{F}$ & $120^{\circ} \mathrm{F}$ & $55^{\circ} \mathrm{F}$ & 72 & 9 & ORNL-2561 \\
\hline ASTM A-285A & $\mathbf{N}^{*}$ & $5 \times 10^{18}$ & $200^{\circ} F$ & $160^{\circ} \mathrm{F}$ & $95^{\circ} \mathrm{F}$ & 44 & 45 & ORNL-2561 \\
\hline ASTM A-285A & & $5 \times 10^{20}$ & $575^{\circ} \mathrm{F}$ & & $85^{\circ} \mathrm{F}$ & $\cdots$ & $\cdots$ & ORNL-2561 \\
\hline
\end{tabular}


TABLE 1 (CONT'D)

\begin{tabular}{|c|c|c|c|c|c|c|c|c|}
\hline Material & Condition & $\begin{array}{l}\text { NVT } \\
\text { Integrated } \\
\text { Flux }>1 \mathrm{Mev} \\
\end{array}$ & $\begin{array}{l}\text { Irrad. } \\
\text { Temp. }\end{array}$ & $\begin{array}{l}\text { Mid-Range } \\
\text { Trans. Temp. }\end{array}$ & $\begin{array}{l}\text { Increase in } \\
\text { Trans. Temp. }\end{array}$ & $\begin{array}{l}\text { Maximum Abs. } \\
\text { Energy Ft. lbs. }\end{array}$ & $\begin{array}{l}\text { \% Decrease } \\
\text { in Max. Abs. } \\
\text { Energy } \\
\end{array}$ & Source of Data \\
\hline $\begin{array}{l}\text { ASTM A-301B } \\
\text { ASTM A-301B }\end{array}$ & $\begin{array}{l}\mathbf{N} \\
\mathbf{N}\end{array}$ & $5 \times 10^{18}$ & $200^{\circ} \mathrm{F}$ & $\begin{array}{l}0^{\circ} \mathrm{F} \\
50^{\circ} \mathrm{F}\end{array}$ & $50^{\circ} \mathrm{F}$ & $\begin{array}{l}6.2 \\
5.2\end{array}$ & 16 & $\begin{array}{l}\text { ORNL-CF-56-11-1 } \\
\text { ORNL-CF-56-11- }\end{array}$ \\
\hline ASTM A-301B & $\ldots$ & & & $90^{\circ} \mathrm{F}$ & $\cdots$ & 60 & $\ldots$ & ORNL-2561 \\
\hline ASTM A-301B & $\ldots--^{*}$ & $1 \times 10^{18}$ & $200^{\circ} \mathrm{F}$ & $110^{\circ} \mathrm{F}$ & $20^{\circ} \mathrm{F}$ & 52 & 13.5 & ORNL-2561 \\
\hline ASTM A-301B & 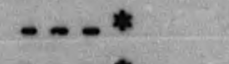 & $5 \times 10_{18}^{18}$ & $200^{\circ} \mathrm{F}$ & $175^{\circ} \mathrm{F}$ & $85^{\circ} \mathrm{F}$ & 27 & 55.5 & ORNL-2561 \\
\hline ASTM A-301B & $\because \cdots *$ & $5 \times 10^{18}$ & $575^{\circ} \mathrm{F}$ & $125^{\circ} \mathrm{F}$ & $35^{\circ} \mathrm{F}$ & 36 & 30 & ORNL-2561 \\
\hline ASTM A-302B & $N \& T^{*}$ & & $\cdots$ & $50^{\circ} \mathrm{F}$ & $\cdots$ & 65 & $\cdots$ & KAPL-1416 \\
\hline ASTM A-302B & $\mathrm{N} \& \mathrm{~T}$ & $3.7 \times 10^{18}$ & $500^{\circ} \mathrm{F}$ & $80^{\circ} \mathrm{F}$ & $30^{\circ} \mathrm{F}$ & 55 & 15 & KAPL-1416 \\
\hline ASTM A-302B & $N \& T^{*}$ & $3.7 \times 10^{18}$ & $700^{\circ} \mathrm{F}$ & $70^{\circ} \mathrm{F}$ & $20^{\circ} \mathrm{F}$ & 60 & 7.5 & KAPL-1416 \\
\hline ASTM A-302B & & $5 \times 10^{18}$ & $200^{\circ} \mathrm{F}$ & & $150^{\circ} \mathrm{F}$ & & $\cdots$ & ORNL-2654 \\
\hline ASTM A-302B & & & & $-101^{\circ} \mathrm{F}$ & & 7.7 & $\ldots$ & Chalk River Data \\
\hline ASTM A-302B & N & $2.4 \times 10^{19}$ & $200^{\circ} \mathrm{F}$ & $77^{\circ} \mathrm{F}$ & $178^{\circ} F$ & 4.7 & $40 \%$ & Chalk River Data \\
\hline ASTM A-302B & N & $3.6 \times 18^{19}$ & $200^{\circ} \mathrm{F}$ & $97^{\circ} \mathrm{F}$ & $198^{\circ} \mathrm{F}$ & 4.3 & $44 \%$ & Chalk River Data \\
\hline ASTM A-302B & $\ldots$ & $2 \times 10^{20}$ & $200^{\circ} \mathrm{F}$ & & $350^{\circ} \mathrm{F}$ & $\cdots-\cdot$ & $\cdots$ & ORNL-2654 \\
\hline ASTM A-201 & HR & & $=-0_{-}$ & $-76^{\circ} \mathrm{F}$ & 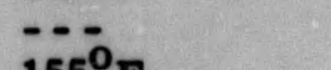 & 7.6 & $=-\cdot$ & A/Conf. 15/P/190 \\
\hline ASTM A-201 & HR & $1.5 \times 10^{19}$ & $200^{\circ} \mathrm{F}$ & $79^{\circ} \mathrm{F}$ & $155^{\circ} \mathrm{F}$ & 7.0 & 8 & A/Conf. $15 / \mathbf{P} / 190$ \\
\hline ASTM A-201 & HR & $2.2 \times 10^{19}$ & $200^{\circ} \mathrm{F}$ & $100^{\circ} \mathrm{F}$ & $176^{\circ} \mathrm{F}$ & 6.4 & 16 & A/Conf. $15 / P / 190$ \\
\hline ASTM A-201 & HR & $4 \times 10^{19}$ & $200^{\circ} \mathbf{F}$ & $151^{\circ} \mathrm{F}$ & $227^{\circ} \mathbf{F}$ & 4.9 & 35 & A/Conf. $15 / \mathrm{P} / 190$ \\
\hline ASTM A-201 & HR & $2.2 \times 10^{19^{2}}$ & $200^{\circ} \mathrm{F}$ & $130^{\circ} \mathrm{F}$ & $206^{\circ} \mathrm{F}$ & 5.6 & 25 & A/Conf. $15 / P / 190$ \\
\hline ASTM A-201 & HR & $2.2 \times 10^{19 b}$ & $200^{\circ} \mathrm{F}$ & $15^{\circ} \mathrm{F}$ & $90^{\circ} \mathrm{F}$ & 7.8 & $2.5^{\mathrm{c}}$ & A/Conf. $15 / \mathrm{P} / 190$ \\
\hline
\end{tabular}


TABLE 1 (CONT'D)

\begin{tabular}{|c|c|c|c|c|c|c|c|c|}
\hline Material & Condition & $\begin{array}{l}\text { NVT } \\
\text { Integrated } \\
\text { Flux }>1 \text { Mev } \\
\end{array}$ & $\begin{array}{l}\text { Irrad. } \\
\text { Temp. }\end{array}$ & $\begin{array}{l}\text { Mid-Range } \\
\text { Trans. Temp. }\end{array}$ & $\begin{array}{l}\text { Increase in } \\
\text { Trans. Temp. }\end{array}$ & $\begin{array}{l}\text { Maximum Abs. } \\
\text { Energy Ft. lbs. }\end{array}$ & $\begin{array}{l}\text { \% Decrease } \\
\text { in Max. Abs. } \\
\text { Energy }\end{array}$ & Source of Data \\
\hline $\begin{array}{l}\text { ASTM A-353 } \\
\text { (9\% Nickel) }\end{array}$ & $\begin{array}{l}\text { DN } 1650^{\circ} \mathrm{F} \\
\text { and } 1450^{\circ} \mathrm{F} \\
\text { and } \mathrm{Reheated} \\
\text { at } 1050^{\circ} \mathrm{F}\end{array}$ & 0 & $\cdots$ & $-320^{\circ} \mathrm{F}$ & $\ldots$ & 3.8 & $\cdots$ & ORNL-CF-56-11-1 \\
\hline $\begin{array}{l}\text { ASTM A-353 } \\
\text { (9\% Nickel) }\end{array}$ & $\begin{array}{l}\text { DN } 1650^{\circ} \mathrm{F} \\
\text { and } 1450^{\circ} \mathrm{F} \\
\text { and Reheated } \\
\text { at } 1050^{\circ} \mathrm{F}\end{array}$ & $5 \times 10^{18}$ & $200^{\circ} \mathrm{F}$ & $-320^{\circ} \mathrm{F}$ & $0^{\circ} \mathrm{F}$ & 3.0 & 20 & ORNL-CF-56-11-1 \\
\hline $\begin{array}{l}\text { ASTM A-353 } \\
\text { (9\% Nickel) }\end{array}$ & $\begin{array}{l}\text { DN } 1650^{\circ} \mathrm{F} \\
\text { and } 1450^{\circ} \mathrm{F} \\
\text { and Reheated } \\
\text { at } 1050^{\circ} \mathrm{F}\end{array}$ & $2 \times 10^{19}$ & $200^{\circ} \mathrm{F}$ & $-180^{\circ} \mathrm{F}$ & $140^{\circ} \mathrm{F}$ & 2.5 & 35 & ORNL-CF-56-11-1 \\
\hline $\begin{array}{l}\text { ASTM A-353 } \\
\text { (9\% Nickel) }\end{array}$ & $\begin{array}{l}\text { DN } 1650^{\circ} \mathrm{F} \\
\text { and } 1450^{\circ} \mathrm{F} \\
\text { and Reheated } \\
\text { at } 1050^{\circ} \mathrm{F}\end{array}$ & $4 \times 10^{19}$ & $200^{\circ} \mathrm{F}$ & $-150^{\circ} \mathrm{F}$ & $170^{\circ} \mathrm{F}$ & 2.0 & 47 & ORNL-ĆF-56-11-1 \\
\hline $\begin{array}{l}\text { ASTM A-353 } \\
\text { (9\% Nickel) }\end{array}$ & $\begin{array}{l}\text { DN } 1650^{\circ} \mathrm{F} \\
\text { and } 1450^{\circ} \mathrm{F} \\
\text { and Reheated } \\
\text { at } 1050^{\circ} \mathrm{F}\end{array}$ & $7 \times 10^{19}$ & $200^{\circ} \mathrm{F}$ & $-125^{\circ} \mathrm{F}$ & $195^{\circ} \mathrm{F}$ & 1.5 & 60 & ORNL-CF-56-11-1 \\
\hline $\begin{array}{l}\text { ASTM A-353 } \\
\text { (9\% Nickel) }\end{array}$ & $\begin{array}{l}\text { DN } 1650^{\circ} \mathrm{F} \\
\text { and } 1450^{\circ} \mathrm{F} \\
\text { and Reheated } \\
\text { at } 1050^{\circ} \mathrm{F}\end{array}$ & $1.2 \times 10^{19}$ & $200^{\circ} \mathrm{F}$ & $-200^{\circ} \mathrm{F}$ & $120^{\circ} \mathrm{F}$ & $\cdots$ & $\cdots$ & Chalk River Data \\
\hline $\begin{array}{l}\text { ASTM A-353 } \\
\text { (9\% Nickel) }\end{array}$ & $\begin{array}{l}\text { DN } 1650^{\circ} \mathrm{F} \\
\text { and } 1450^{\circ} \mathrm{F} \\
\text { and Reheated } \\
\text { at } 1050^{\circ} \mathrm{F}\end{array}$ & $4.4 \times 10^{19}$ & $200^{\circ} \mathrm{F}$ & $-175^{\circ} F$ & $145^{\circ} \mathrm{F}$ & $\cdots$ & $\cdots$ & Chaik River Data \\
\hline $\begin{array}{l}\text { ASTM A-203 } \\
\text { Grade D } \\
\text { (3-1/2\% Nickel) }\end{array}$ & $\cdots$ & 10 & $\cdots$ & $-200^{\circ} F$ & $\cdots$ & $\cdots$ & $\cdots$ & Chalk River Data \\
\hline $\begin{array}{l}\text { ASTM A-203 } \\
\text { Grade D } \\
\text { (3-1/2\% Nickel) }\end{array}$ & $\cdots$ & $2.4 \times 10^{19}$ & $200^{\circ} \mathrm{F}$ & $28^{\circ} \mathrm{F}$ & $228^{\circ} \mathrm{F}$ & $\cdots$ & $\cdots$ & Chalk River Data \\
\hline $\begin{array}{l}\text { AsTM A-203 } \\
\text { Grade D } \\
\text { (3-1/2\% Nickel) }\end{array}$ & ... & $3.6 \times 10^{19}$ & $200^{\circ} \mathrm{F}$ & $68^{\circ} \mathrm{F}$ & $268^{\circ} \mathrm{F}$ & $\ldots$ & $\ldots$ & Chalk River Data \\
\hline
\end{tabular}


TABLE 1 (CONT" D)

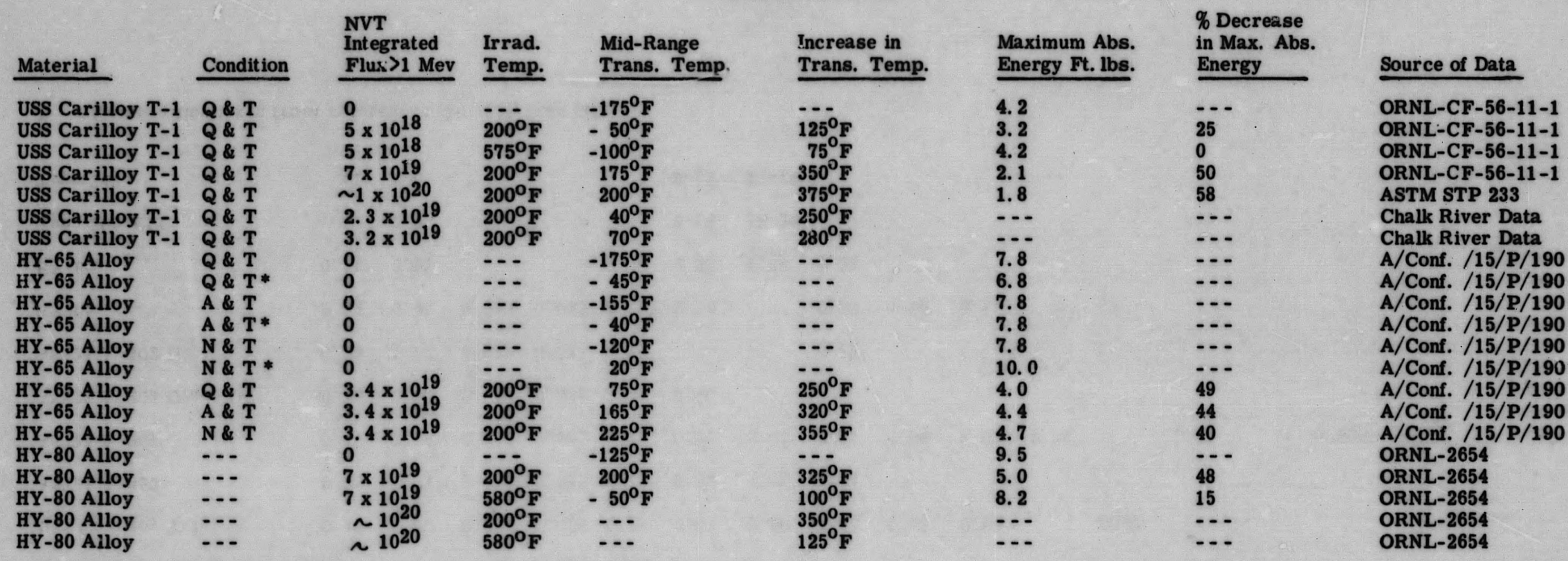

Notes: ** Data from references (2), (11), (16), (20), (26), (30), (31), (32), (33), (34), (35).

" Represents Charpy "V" Notch Data. All others Sub-size Izod Data.

+ Followed by a 2 hour anneal @ $300^{\circ} \mathrm{F}$.

Followed by a 6 hour anneal @ $500^{\circ} \mathrm{F}$.

Followed by a 6 hour anneal (3) $635^{\circ} \mathrm{F}$.

c Represents an increase rather than the decrease normally observed.

-.- Represents unknown condition of material or energy-temperature data. 
TABLE 2

COMPOSITION OF CARBON, LOW ALLOY, AND STAINL ESS STEEL STRUCTURAL MATERIALS*

\begin{tabular}{|c|c|c|c|c|c|c|c|c|c|c|c|c|c|c|c|c|}
\hline Material & c & $\underline{\mathrm{Mn}}$ & $\underline{P}$ & $\underline{s}$ & $\underline{\mathbf{S i}}$ & $\underline{\mathrm{Ni}}$ & $\underline{\mathrm{Cr}}$ & $\underline{\text { Mo }}$ & Cu & $\underline{\mathbf{v}}$ & $\underline{w}$ & $\underline{\mathbf{B}}$ & $\underline{\text { AL }}$ & $\underline{\mathrm{Sn}}$ & $\mathrm{N}_{2}$. & Co $\quad \underline{C b}$ \\
\hline ASTM A-212B & 0.20 & 0.82 & .018 & .030 & 0.22 & & & & & & & & & & & \\
\hline ASTM A-285 & 0.11 & 0.36 & .018 & .02 & & & & & & & & & & & & \\
\hline ASTM A-301B & 0.11 & 0.36 & 0.02 & 0.026 & 0.22 & & 0.98 & 0.67 & & & & & & & & \\
\hline ASTM A-106 (Coarse) & 0.24 & 0.72 & .018 & .023 & 0.20 & & & & & & & & & & & \\
\hline ASTM A-106 (Fine) & 0.24 & 0.70 & .019 & .020 & 0.19 & & & & & & & & & & & \\
\hline USS Carilloy T-1 & 0.16 & 0.93 & 0.014 & 0.023 & 0.26 & 0.87 & 0.50 & 0.45 & 0.33 & 0.06 & & .0031 & & & & \\
\hline ASTM A-353 & 0.09 & 0.71 & 0.015 & 0.015 & 0.11 & 8. 83 & 0.23 & 0.04 & & & & & & & & \\
\hline ASTM A-201 & 0.17 & 0.55 & 0.020 & 0.022 & 0.21 & 0.05 & 0.04 & 0.01 & 0.06 & 0.02 & 0.04 & & 0.04 & & 0.005 & \\
\hline ASTM A-203 Grade D & 0.13 & 0.60 & 0.022 & 0.032 & 0.22 & 3.40 & & & & & & & & & & \\
\hline ASTM A-302 B & 0.20 & 1.32 & 0.022 & 0.03 & 0.25 & & & 0.42 & & & & & & & & \\
\hline HY-65 & 0.12 & 0.48 & 0.013 & 0.032 & 0.21 & 2.16 & & 0.39 & 0.70 & 0.11 & & & & & & \\
\hline HY -80 & 0.18 & 0.25 & & & & 2. 38 & 1.34 & 0.22 & & & & & & & & \\
\hline Type 304 ELC & .03 & 2.0 & & & & $8-12$ & $18-20$ & & & & & & & & & \\
\hline Type 347 & .08 & 2.0 & & & & $9-12$ & $17-19$ & & & & & & & & & $10 \times C$ \\
\hline
\end{tabular}


TABLE 3

PRE-AND POST-IRRADIATION MECHANICAL PROPERTIES OF VARIOUS CARBON AND LOW ALLOY STEELS*

\begin{tabular}{|c|c|c|c|c|c|}
\hline Material & $\underline{\text { NVT }}$ & Irrad. Temp. & Yield Strength & Tensile Strength & $\begin{array}{l}\text { Uniform } \\
\text { Elongation }\end{array}$ \\
\hline $\begin{array}{l}\text { ASTM A-212B } \\
\text { ASTM A-212B } \\
\text { ASTM A-212B } \\
\text { ASTM A-212B } \\
\text { ASTM A-212B } \\
\text { ASTM A-212B } \\
\text { ASTM A-212B } \\
\text { ASTM A-212B }\end{array}$ & $\begin{array}{l}0 \\
1 \times 10^{19} \\
1 \times 10^{20} \\
2 \times 10^{19} \\
2 \times 10^{19} \\
2 \times 10^{19} \\
6 \times 10^{19} \\
6 \times 10^{19}\end{array}$ & $\begin{array}{l}200^{\circ} \mathrm{F} \\
200^{\circ} \mathrm{F} \\
560^{\circ} \mathrm{F} \\
680^{\circ} \mathrm{F} \\
760^{\circ} \mathrm{F} \\
700^{\circ} \mathrm{F} \\
780^{\circ} \mathrm{F}\end{array}$ & $\begin{array}{l}51,000 \mathrm{psi} \\
65,400 \mathrm{psi} \\
93,000 \mathrm{psi} \\
76,000 \mathrm{psi} \\
61,000 \mathrm{psi} \\
56,000 \mathrm{psi} \\
82,000 \mathrm{psi} \\
59,000 \mathrm{psi}\end{array}$ & $\begin{array}{r}75,000 \mathrm{psi} \\
80,800 \mathrm{psi} \\
97,000 \mathrm{psi} \\
102,000 \mathrm{psi} \\
90,000 \mathrm{psi} \\
84,000 \mathrm{psi} \\
105,000 \mathrm{psi} \\
81,000 \mathrm{psi}\end{array}$ & $\begin{array}{r}23 \% \\
18 \% \\
5 \% \\
9 \% \\
12 \% \\
14 \% \\
6 \% \\
13 \%\end{array}$ \\
\hline $\begin{array}{l}A-301 B \\
A-301 B \\
A-301 B \\
A-301 B \\
A-301 B \\
A-301 B\end{array}$ & $\begin{array}{l}0 \\
5 \times 10^{18} \\
5 \times 10^{18} \\
1.5 \times 10^{19} \\
4.5 \times 10^{19} \\
4.5 \times 10^{19}\end{array}$ & $\begin{array}{l}200^{\circ} \mathrm{F} \\
5755^{\circ} \mathrm{F} \\
740^{\circ} \mathrm{F} \\
740^{\circ} \mathrm{F} \\
700^{\circ} \mathrm{F}\end{array}$ & $\begin{array}{l}41,000 \mathrm{psi} \\
55,000 \mathrm{psi} \\
47,000 \mathrm{psi} \\
53,000 \mathrm{psi} \\
63,000 \mathrm{psi} \\
91,000 \mathrm{psi}\end{array}$ & $\begin{array}{r}66,000 \mathrm{psi} \\
69,000 \mathrm{psi} \\
71,000 \mathrm{psi} \\
78,000 \mathrm{psi} \\
86,000 \mathrm{psi} \\
103,000 \mathrm{psi}\end{array}$ & $\begin{array}{l}23 \% \\
23 \% \\
26 \% \\
18 \% \\
12 \% \\
-\end{array}$ \\
\hline $\begin{array}{l}\text { ASTM A-201 } \\
\text { ASTM A-201 } \\
\text { ASTM A-201 } \\
\text { ASTM A-201 } \\
\text { ASTM A-201 } \\
\text { ASTM A-201 } \\
\text { ASTM A-201 }\end{array}$ & $\begin{array}{l}0 \\
7.8 \times 10^{18} \\
1.47 \times 10^{19} \\
2.1 \times 10^{19} \\
4.0 \times 10^{19} \\
1.03 \times 10^{19} \\
2.46 \times 10^{19}\end{array}$ & $\begin{array}{l}200^{\circ} \mathrm{F} \\
200^{\circ} \mathrm{F} \\
200^{\circ} \mathrm{F} \\
200^{\circ} \mathrm{F} \\
425^{\circ} \mathrm{F}-515^{\circ} \mathrm{F} \\
525^{\circ} \mathrm{F}-700^{\circ} \mathrm{F}\end{array}$ & $\begin{array}{l}47,600 \mathrm{psi} \\
76,600 \mathrm{psi} \\
77,500 \mathrm{psi} \\
88,500 \mathrm{psi} \\
94,300 \mathrm{psi} \\
59,800 \mathrm{psi} \\
53,600 \mathrm{psi}\end{array}$ & $\begin{array}{l}75,000 \mathrm{psi} \\
82,200 \mathrm{psi} \\
82,800 \mathrm{psi} \\
92,800 \mathrm{psi} \\
98,000 \mathrm{psi} \\
84,200 \mathrm{psi} \\
82,600 \mathrm{psi}\end{array}$ & $\begin{array}{l}31 \% \\
17 \% \\
15 \% \\
13 \% \\
9.5 \% \\
16.3 \% \\
21.0 \%\end{array}$ \\
\hline $\begin{array}{l}\text { ASTM A-203D } \\
\text { (3-1/2\% nickel) }\end{array}$ & 0 & $200^{\circ} \mathrm{F}$ & $66,600 \mathrm{psi}$ & $85,900 \mathrm{psi}$ & $25 \%$ \\
\hline $\begin{array}{l}\text { ASTM A-203D } \\
\text { (3-1/2\% nickel) }\end{array}$ & $2.4 \times 10^{19}$ & $200^{\circ} \mathrm{F}$ & $122,400 \mathrm{psi}$ & $122,600 \mathrm{psi}$ & $10 \%$ \\
\hline $\begin{array}{l}\text { ASTM A-203D } \\
\text { (3-1/2\% nickel) }\end{array}$ & $3.6 \times 10^{19}$ & $200^{\circ} \mathrm{F}$ & $133,000 \mathrm{psi}$ & $133,000 \mathrm{psi}$ & $9 \%$ \\
\hline $\begin{array}{l}\text { ASTM A-353 } \\
\text { (9\% nickel) }\end{array}$ & 0 & (n) & $114,200 \mathrm{psi}$ & $137,600 \mathrm{psi}$ & $17 \%$ \\
\hline $\begin{array}{l}\text { ASTM A-353 } \\
\text { (9\% nickel) }\end{array}$ & $2.4 \times 10^{19}$ & $200^{\circ} \mathrm{F}$ & $156,300 \mathrm{psi}$ & $160,600 \mathrm{psi}$ & $10.5 \%$ \\
\hline $\begin{array}{l}\text { ASTM A-353 } \\
\text { (9\% nickel) }\end{array}$ & 2. $8 \times 10^{19}$ & $200^{\circ} \mathrm{F}$ & $167,000 \mathrm{psi}$ & $172,000 \mathrm{psi}$ & $10.6 \%$ \\
\hline $\begin{array}{l}\text { ASTM A-302B } \\
\text { ASTM A-302B } \\
\text { ASTM A-302B }\end{array}$ & $\begin{array}{l}0 \\
2.4 \times 10^{19} \\
3.6 \times 10^{19}\end{array}$ & $200^{\circ} \mathrm{F}$ & $\begin{array}{r}68,500 \text { psi } \\
118,600 \text { psi } \\
122,400 \text { psi }\end{array}$ & $\begin{array}{r}89,200 \mathrm{psi} \\
118,700 \mathrm{psi} \\
122,800 \mathrm{psi}\end{array}$ & $\begin{array}{l}23 \% \\
11 \% \\
10.5 \%\end{array}$ \\
\hline $\begin{array}{l}\text { ASTM A-106 } \\
\text { (fine grain) }\end{array}$ & 0 & $\cdots$ & $40,000 \mathrm{psi}$ & 76,000 psi & $18 \%$ \\
\hline $\begin{array}{l}\text { ASTM A-106 } \\
\text { (fine grain) }\end{array}$ & $2 \times 10^{19}$ & $580^{\circ} \mathrm{F}$ & $81,000 \mathrm{psi}$ & $102,000 \mathrm{psi}$ & $8 \%$ \\
\hline $\begin{array}{l}\text { ASTM A-106 } \\
\text { (fine grain) }\end{array}$ & $2 \times 10^{19}$ & $680^{\circ} \mathrm{F}$ & $55,000 \mathrm{psi}$ & $87,000 \mathrm{psi}$ & $11 \%$ \\
\hline $\begin{array}{l}\text { ASTM A-106 } \\
\text { (fine grain) }\end{array}$ & $2 \times 10^{19}$ & $760^{\circ} \mathrm{F}$ & $48,000 \mathrm{psi}$ & 82,000 psi & $12 \%$ \\
\hline $\begin{array}{l}\text { ASTM A-106 } \\
\text { (fine grain) }\end{array}$ & & $580^{\circ} \mathrm{F}$ & $79,000 \mathrm{pai}$ & $106,000 \mathrm{psi}$ & $6 \%$ \\
\hline & $8 \times 10^{19}$ & $780^{\circ} \mathrm{F}$ & $47,000 \mathrm{psi}$ & $79,000 \mathrm{psi}$ & $11 \%$ \\
\hline $\begin{array}{l}\text { ASTM A-106 } \\
\text { (fine grain) }\end{array}$ & $1 \times 10^{20}$ & $175^{\circ} \mathrm{F}$ & 97,000 psi & $102,000 \mathrm{psi}$ & $4 \%$ \\
\hline $\begin{array}{l}\text { ASTM A-106 } \\
\text { (coarse grain) }\end{array}$ & 0 & (n) & $46,000 \mathrm{psi}$ & $80,000 \mathrm{psi}$ & $14 \%$ \\
\hline $\begin{array}{l}\text { ASTM A-106 } \\
\text { (coarse grain) }\end{array}$ & $2 \times 10^{19}$ & $580^{\circ} \mathrm{F}$ & $93,000 \mathrm{psi}$ & $115,000 \mathrm{psi}$ & $8 \%$ \\
\hline $\begin{array}{l}\text { ASTM A-106 } \\
\text { (coarse grain) }\end{array}$ & $2 \times 10^{19}$ & $680^{\circ} \mathrm{F}$ & $67,000 \mathrm{psi}$ & $98,000 \mathrm{psi}$ & $9 \%$ \\
\hline $\begin{array}{l}\text { ASTM A-106 } \\
\text { (coarse grain) }\end{array}$ & $2 \times 10^{19}$ & $760^{\circ} \mathrm{F}$ & $43,000 \mathrm{psi}$ & $84,000 \mathrm{psi}$ & $14 \%$ \\
\hline $\begin{array}{l}\text { ASTM A-106 } \\
\text { (coarse grain) }\end{array}$ & $7 \times 10^{19}$ & $580^{\circ} \mathrm{F}$ & $87,000 \mathrm{psi}$ & $103,000 \mathrm{psi}$ & $3 \%$ \\
\hline $\begin{array}{l}\text { ASTM A-106 } \\
\text { (coarse grain) }\end{array}$ & $7 \times 10^{19}$ & $780^{\circ} \mathrm{F}$ & $64,000 \mathrm{psi}$ & 94,000 psi & $11 q$ \\
\hline $\begin{array}{l}\text { ASTM A-106 } \\
\text { (coarse grain) }\end{array}$ & $1 \times 10^{20}$ & $175^{\circ} \mathrm{F}$ & $116,000 \mathrm{psi}$ & $121,000 \mathrm{psi}$ & $2 \%$ \\
\hline
\end{tabular}

- Data taken from Ref. (20), (21) 
TABLE 4

EFFECTS OF LONG EXPOSURE AT $700^{\circ} \mathrm{F}$ ON THE CHARPY "V" NOTCH 15-MIL TRANSITION TEMPERATURE OF ASTM A-353

( $9 \%$ NICKEL STEEL)*

\section{Condition}

As double normalized $\left(1650^{\circ} \mathrm{F}\right.$ and $\left.1450^{\circ} \mathrm{F}\right)$ and stress relieved at $1050^{\circ} \mathrm{F}$

After 100 hrs. at $700^{\circ} \mathrm{F}$

After 200 hrs. at $700^{\circ} \mathrm{F}$

After 500 hrs. at $700^{\circ} \mathrm{F}$

After $1000 \mathrm{hrs}$. at $700^{\circ} \mathrm{F}$

After 7000 hrs. at $700^{\circ} \mathrm{F}$

After 8200 hrs. at $700^{\circ} \mathbf{F}$

Re-stress relieved at $1050^{\circ} \mathrm{F}$

after $8200 \mathrm{hrs}$. at $700^{\circ} \mathrm{F}$

- Data from Ref. (35)
Charpy V-noteh 15 mil Transition Temperature

$-270^{\circ} \mathbf{F}$

$-270^{\circ} \mathbf{F}$

$-200^{\circ} \mathrm{F}$

$-200^{\circ} \mathrm{F}$

$-140^{\circ} \mathrm{F}$

$-40^{\circ} \mathrm{F}$

$-50^{\circ} \mathrm{F}$

$-290^{\circ} \mathrm{F}$

TABLE 5

EFFECTS OF LONG EXPOSURE AT $500^{\circ} \mathrm{F}$ AND $700^{\circ} \mathrm{F}$ ON THE CHARPY "V" NOTCH 15-MIL TRANSITION TEMPERATURE OF ASTM A-203 GRADE D (3-1/2\% NICKEL STEEL)**

Condition

Charpy "v" Notch

As normalized and stress relieved at $1150^{\circ} \mathrm{F}$

15 mil Transition Temperature

After 1 hour at $500^{\circ} \mathrm{F}$

$-130^{\circ} \mathrm{F}$

After 2000 hours at $500^{\circ} \mathrm{F}$

$-137^{\circ} \mathrm{F}$

After 8000 hours at $500^{\circ} \mathrm{F}$

$-125^{\circ} \mathrm{F}$

After 1 hour at $700^{\circ} \mathrm{F}$

$-145^{\circ} \mathrm{F}$

Alter 1 hour at $700^{\circ}$.

$-137^{0} \mathrm{~F}$

After 2000 hours at $700^{\circ} \mathrm{F}$

$-103^{\circ} \mathrm{F}$

After 8000 hours at $700^{\circ} \mathrm{F}$

$-45^{\circ} \mathrm{F}$

** Data from Ref. (35) 


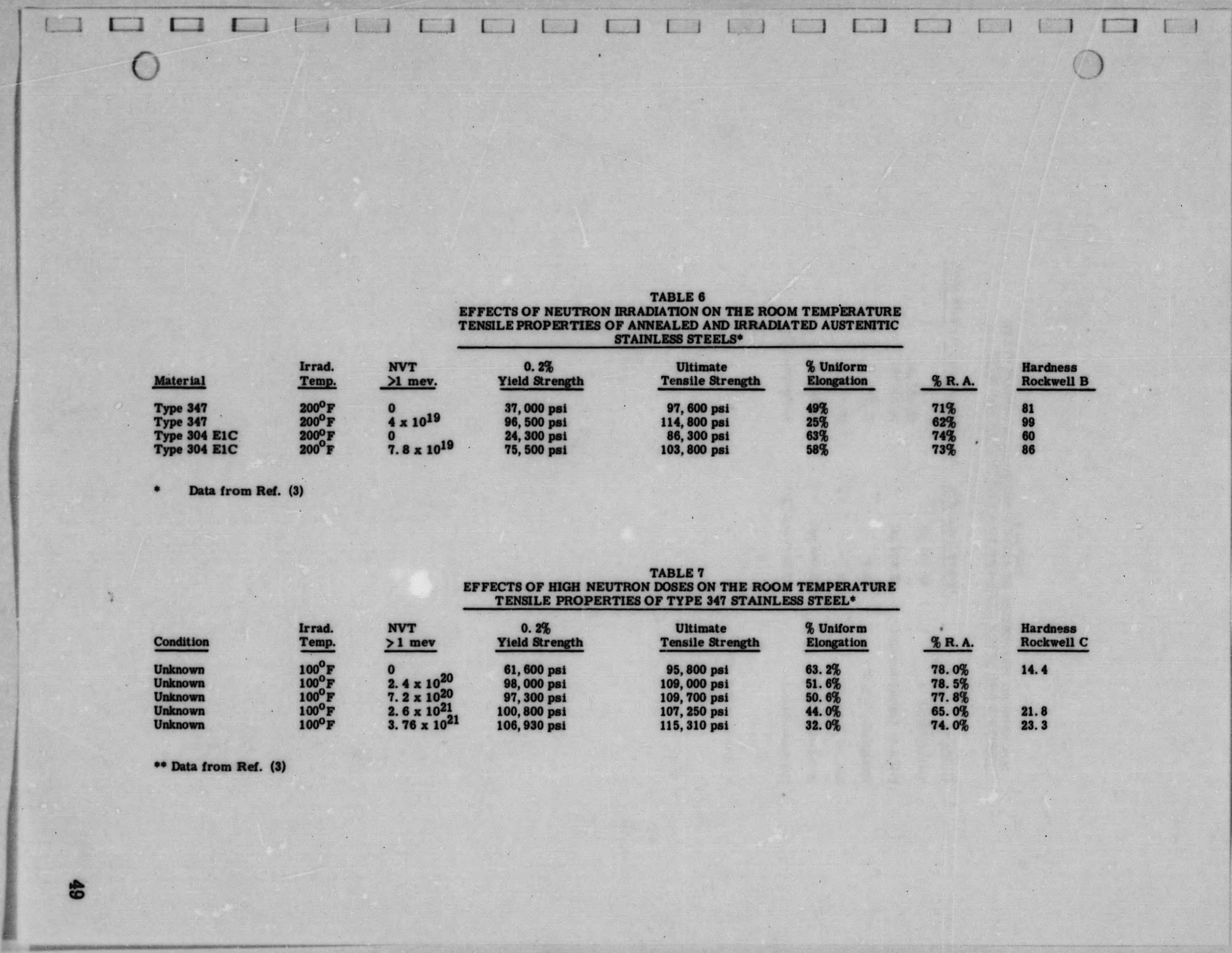


TABLE 8

MECHANICAL PROPERTIES OF ASTM A-201 GRADE B CARBON STEEL BEFORE AND AFTER EXPOSURE TO $4 \times 10^{19}$ NVT IN THE MTR*

\section{Property}

Yield Strength

Ultimate Tensile Strength

Elongation, \% in 2"

Red. of Area, \%

Breaking Strength

Hardness (Mas.)

Data from Ref. (29)
Before Irradiation After MTR Service $\left(4 \times 10^{19}\right.$ NVT) 43, 000 psi

72, 800 psi

46, 500 psi

76, 000 psi

41.0

29.0

53

50

127, 000 psi

125, 000 psi

75 Rockwell "B" 


\subsection{APPENDIX FIGURES}

\section{LIST OF APPENDIX FIGURES}

FIGURE

TITLE

PAGE

Calculated 20 Year "NVT" Values for Various SM-2 Reactor Vessel Designs vs. Inside Dia-

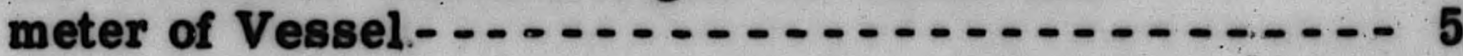

Increase in Mid-Range Transition Temperature v8. Integrated Neutron Flux $>1 \mathrm{Mev}$ for SubSize Izod Specimens of ASTM A-212B, ASTM A-201, ASTM A-106A, ASTM A-285A, ASTM A-301B, and ASTM A-302B Ferritic Steels-_-

Increase in Mid-Range Transition Temperature.v8. Integrated Neutron Flux $>1$ Mev for Sub-Size Izod Specimens of ASTM A-353, ASTM A-203 Grade D, USS Carilloy T-1, HY-65 Alloy, and HY-80 Alloy-... 5

Increase in Mid-Range Transition Temperature vs. Integrated Neutron Flux $>1 \mathrm{Mev}$ for Sub-Size Specimens of ASTM A-212B Carbon Silicon Steel

Mid-Range Transition Temperature vs. Integrated Neutron Flux $>1$ Mev for Sub-Size Izod Specimens of ASTM A-212B, ASTM A-201, ASTM A106A, ASTM A-285A, ASTM A-301B, and ASTM A-302B Ferritic Steels

Mid-Range Transition Temperature vs. Integrated Neutron Flux $>1$ Mev for Sub-Size Izod Specimens of ASTM A-353, ASTM A-203 Grade D, USS Carilloy T-1, HY-65, Alloy and HY -80 Alloy $\ldots \ldots . .66$

Correlation of Charpy "V" Notch and Drop Weight

Tests of Several Materials after Irradiation _.....

Increase in Mid-Range Transition Temperature vs.

Integrated Neutron Flux $>1$ Mev for Full Size Charpy "V" Notch Specimens of ASTM A-212B, ASTM A-285, ASTM A-301B, and ASTM A-302B -...- 


\section{LIST OF APPENDIX FIGURES (CONT" D)}

FIGURE

TITLE

PAGE

9

Percentage Decrease in Maximum Absorbed Energy from Unirradiated Condition vs. Integrated Neutron Flux $>1$ Mev for Sub-Size Izod Spec:mens of ASTM A-212B, ASTM A-201, ASTM A-106A, ASTM A-285A, ASTM A-301B, aind ASTM A-302B- . . . .

Percentage Decrease in Maximum Absorbed Energy from Unirradiated Condition vs. Integrated Neutron Flux $>1$ Mev for Sub-Size Izod Specimens of AST M A-353, ASTM A-203 Grade D, USS Carilloy T-1, HY-65 Alloy and HY-80 Alloy -

11 Impact Energy vs. Tempering Temperature for $9 \%$ Nickel Steel, Double Normalized, Tempered 1 Hour and Air Cooled ................ 


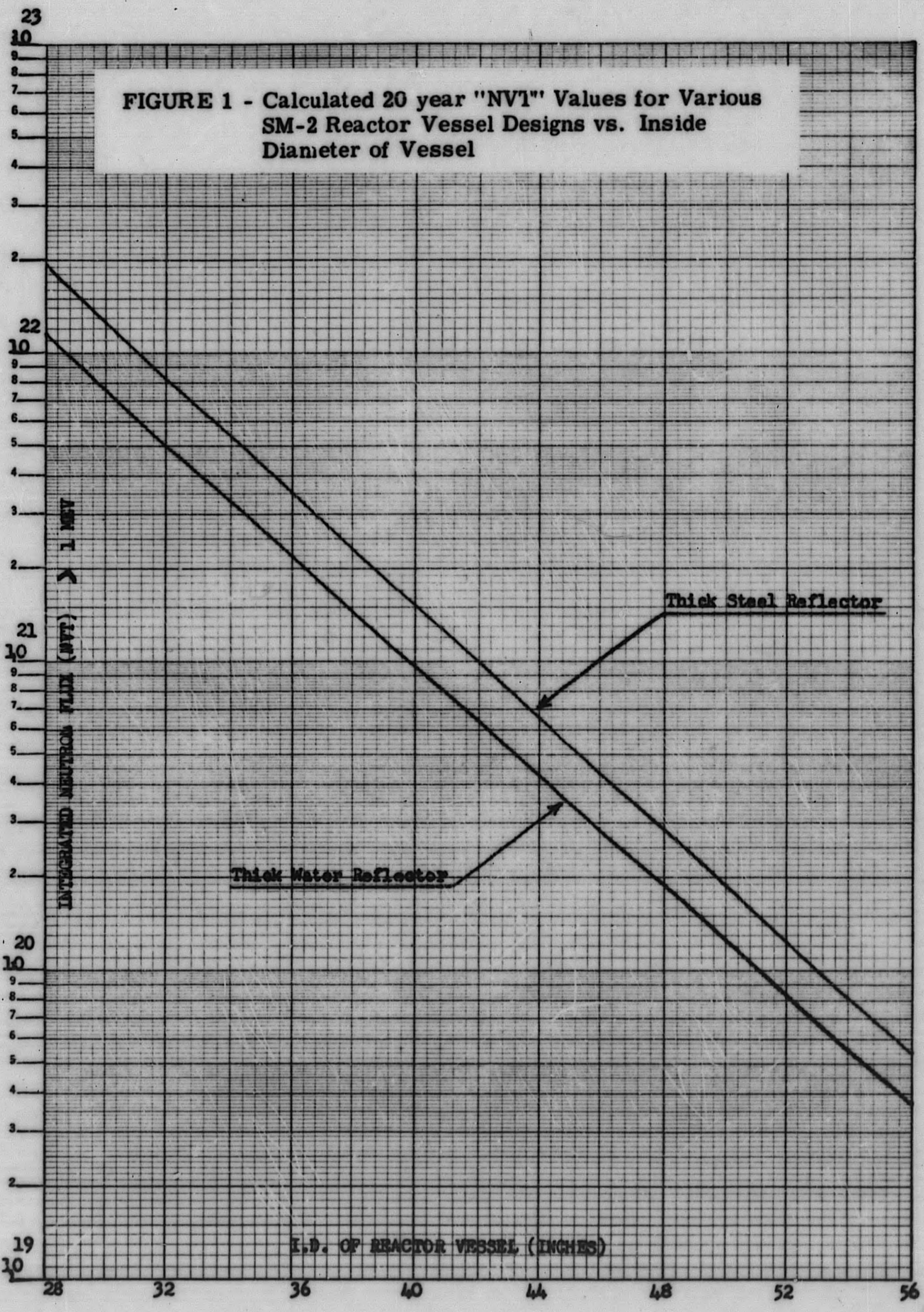




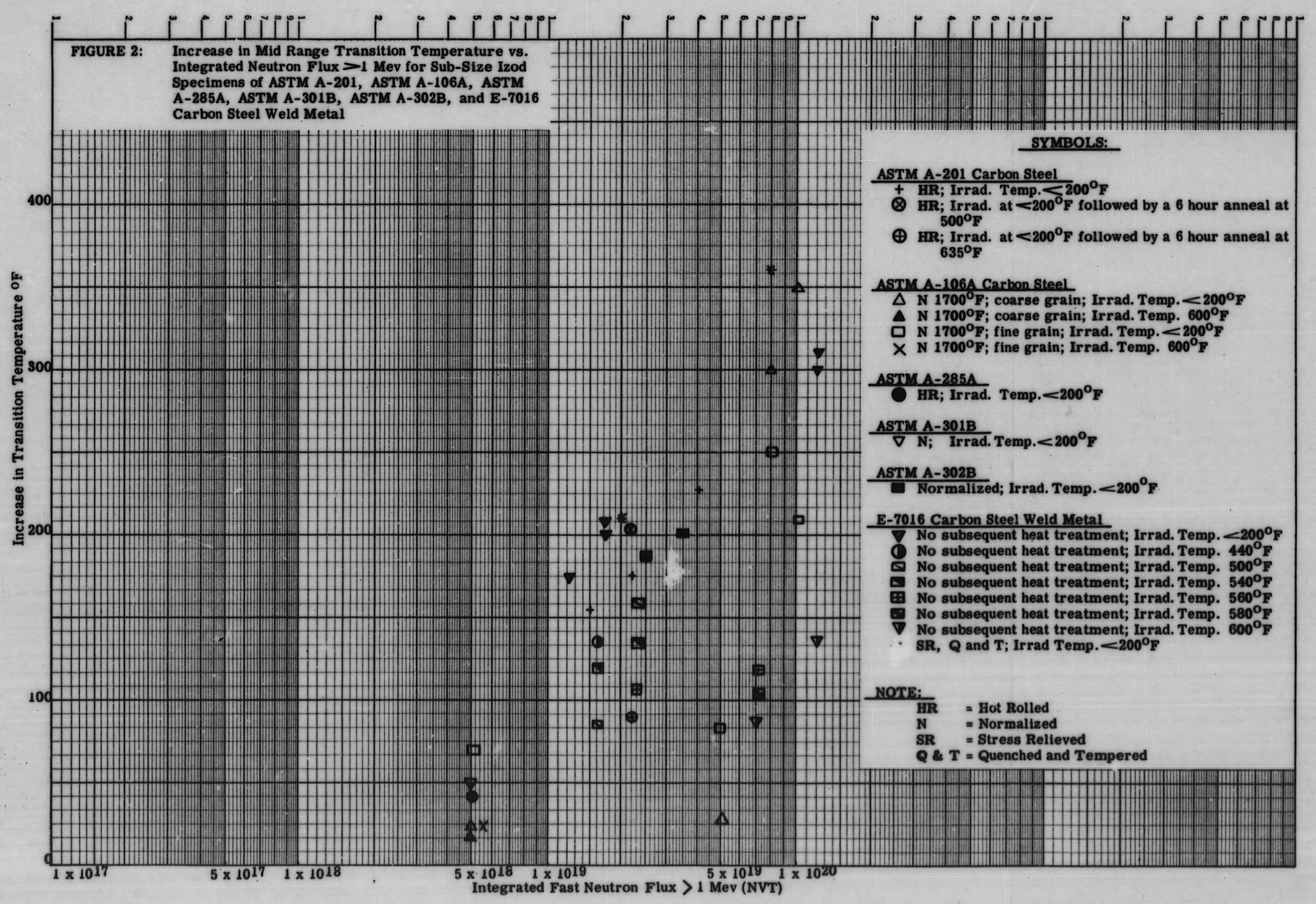




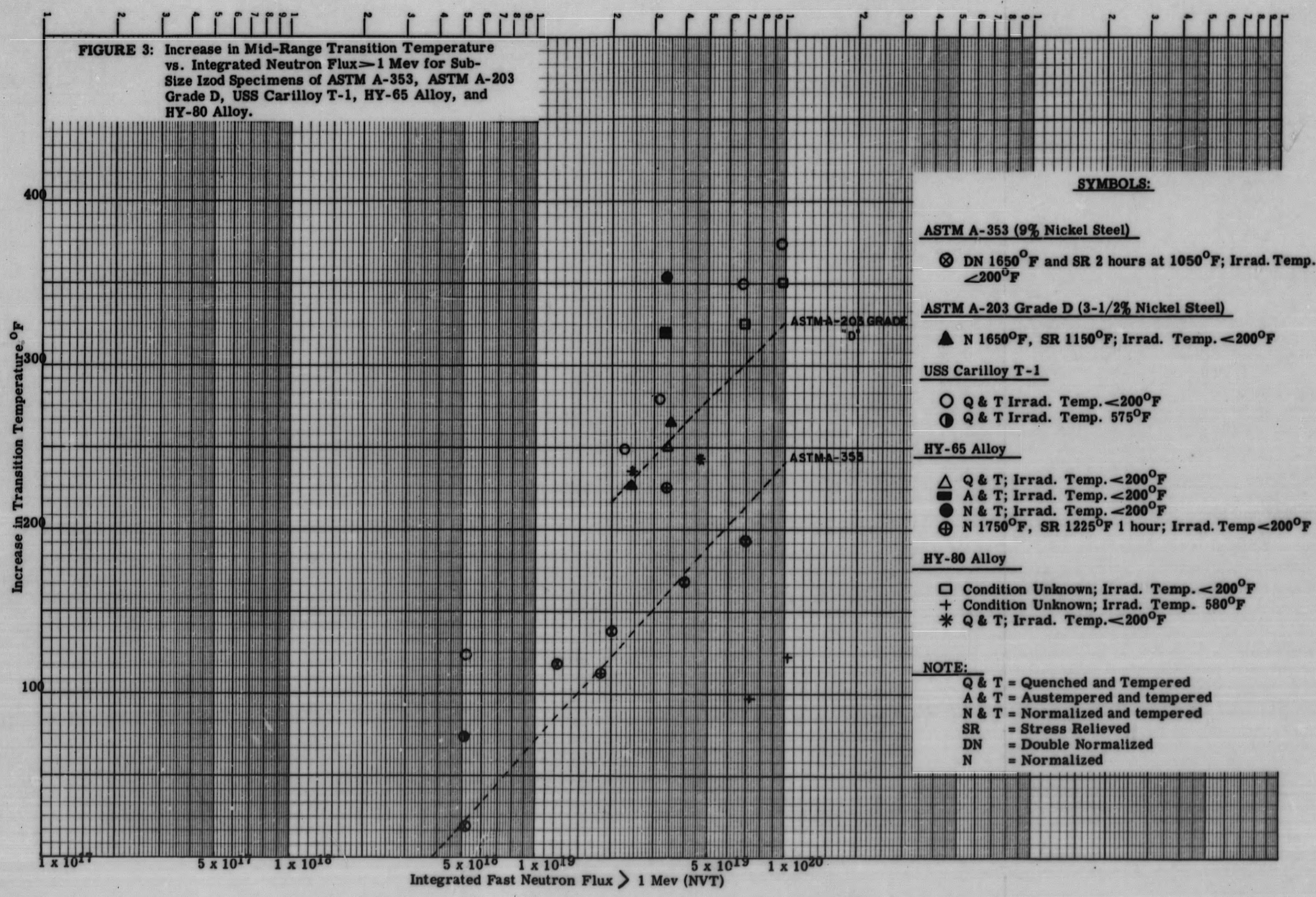

Integrated Fast Neutron Flux $>1$ Mev (NVT) 


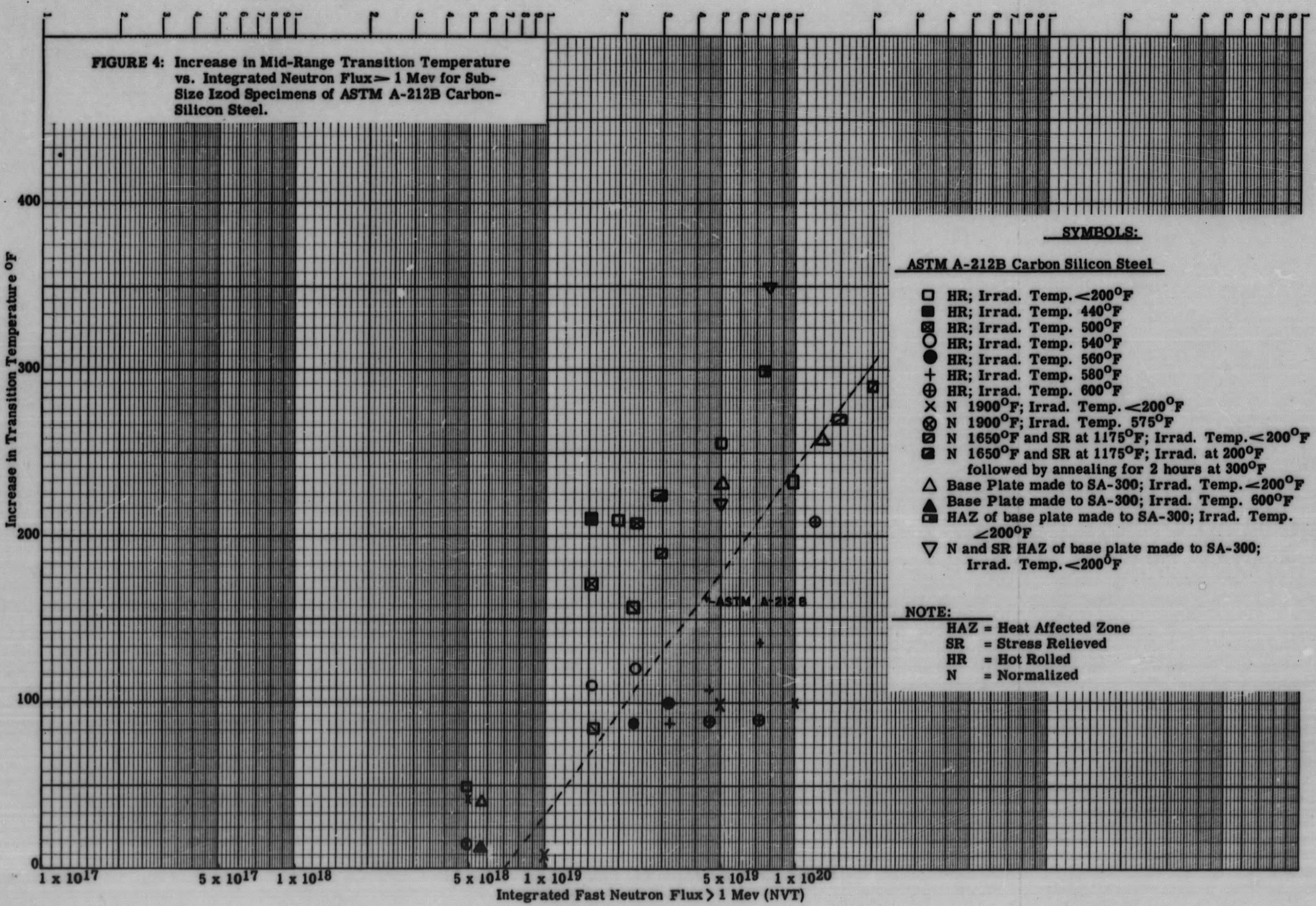




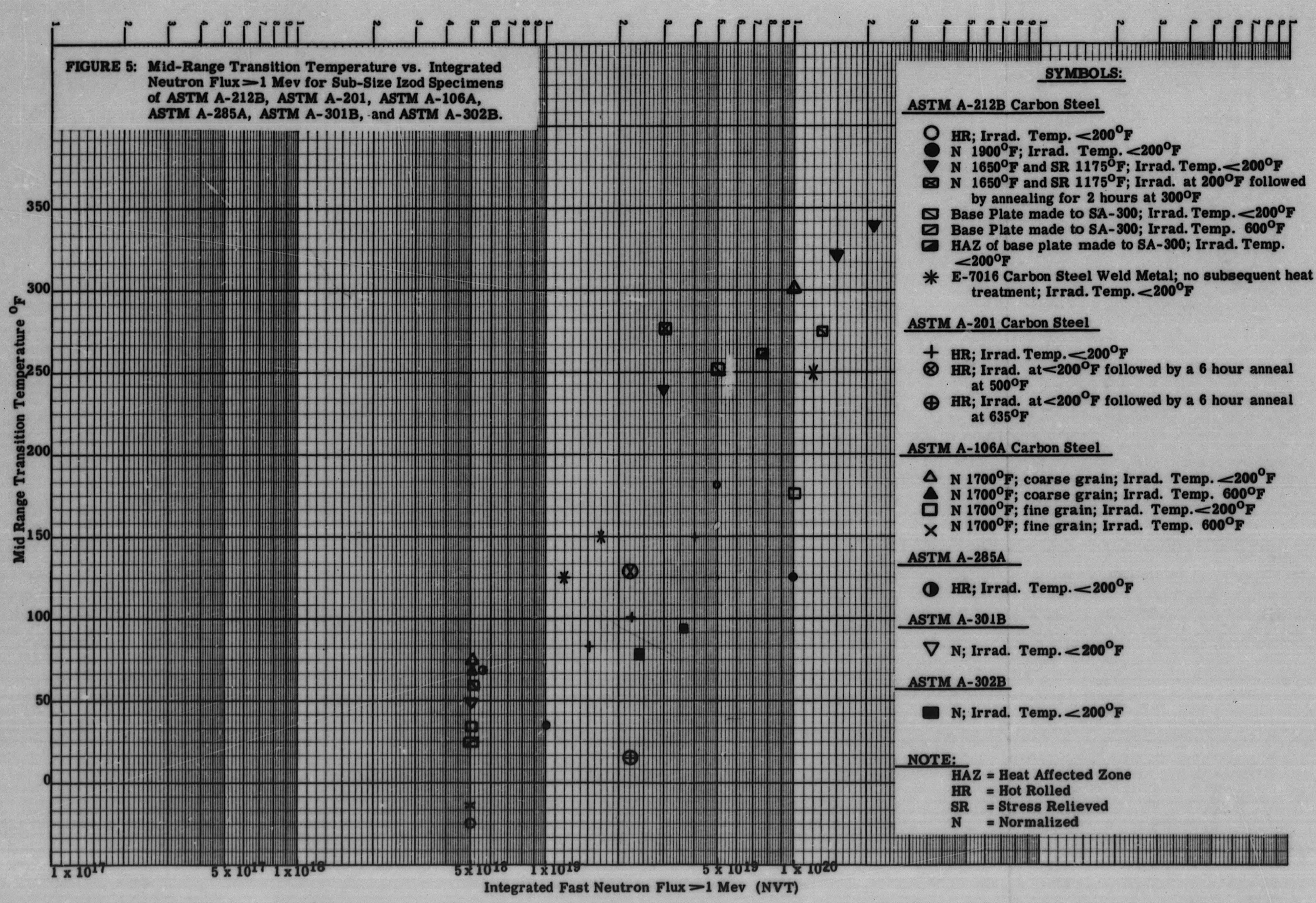




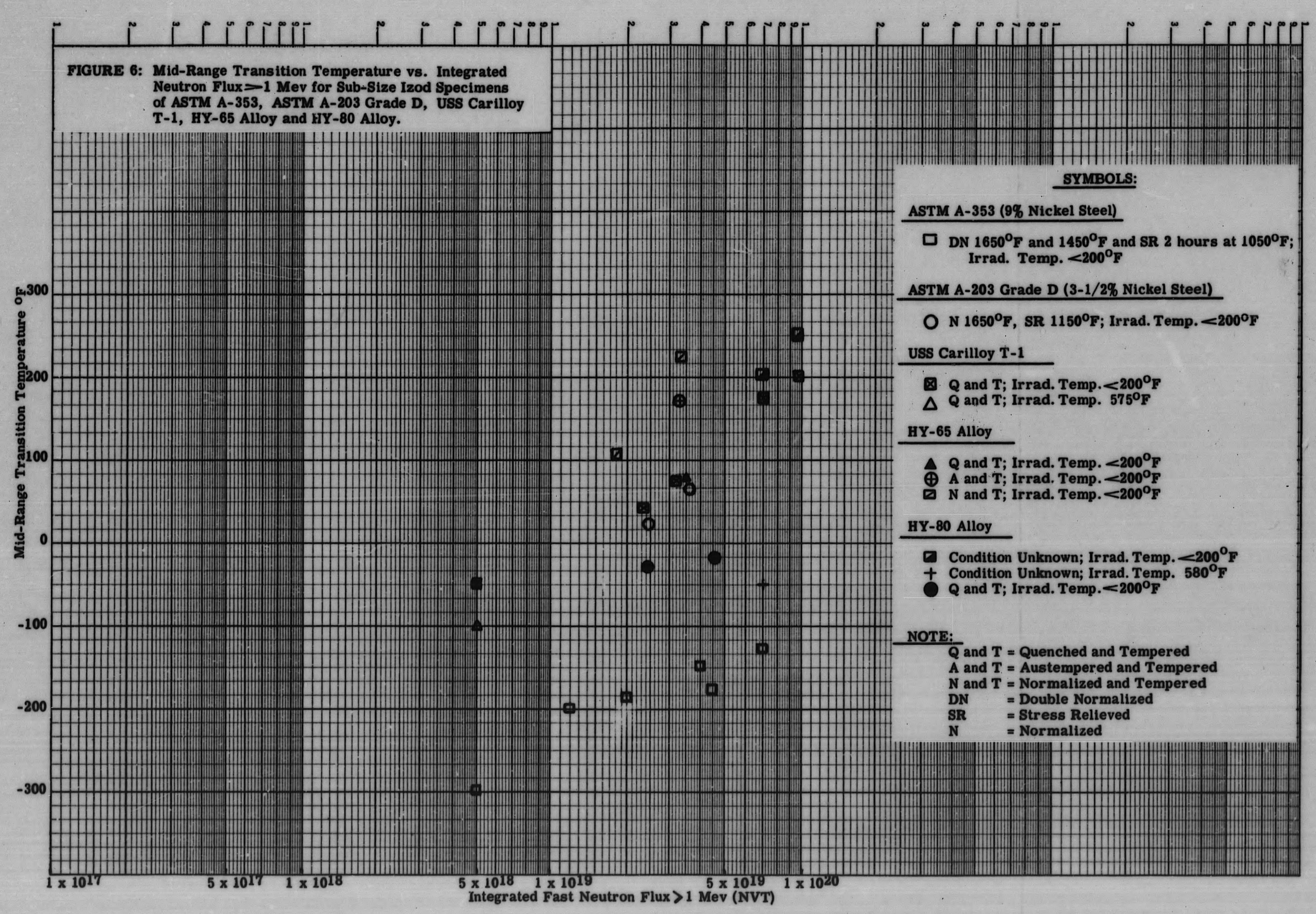




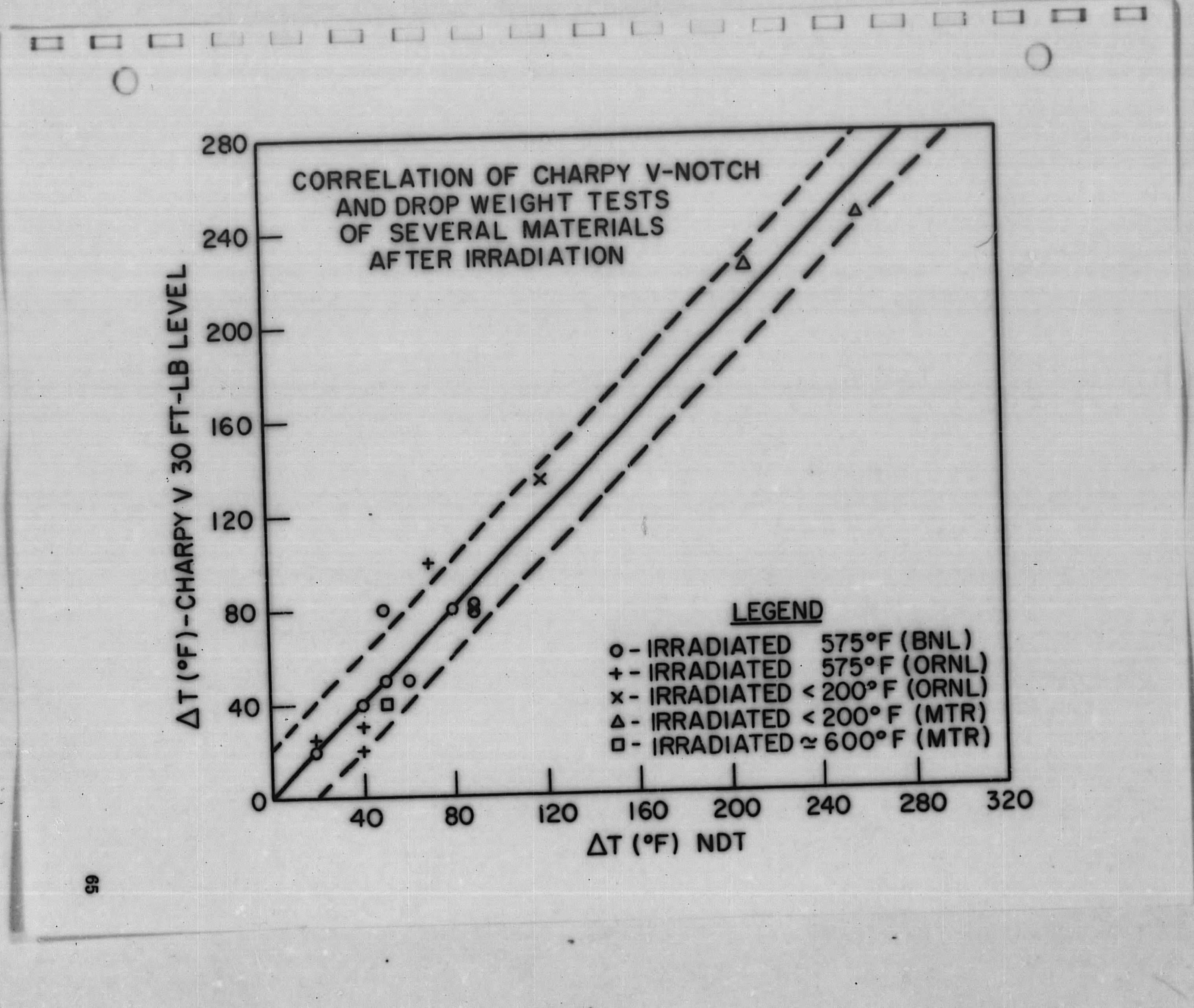




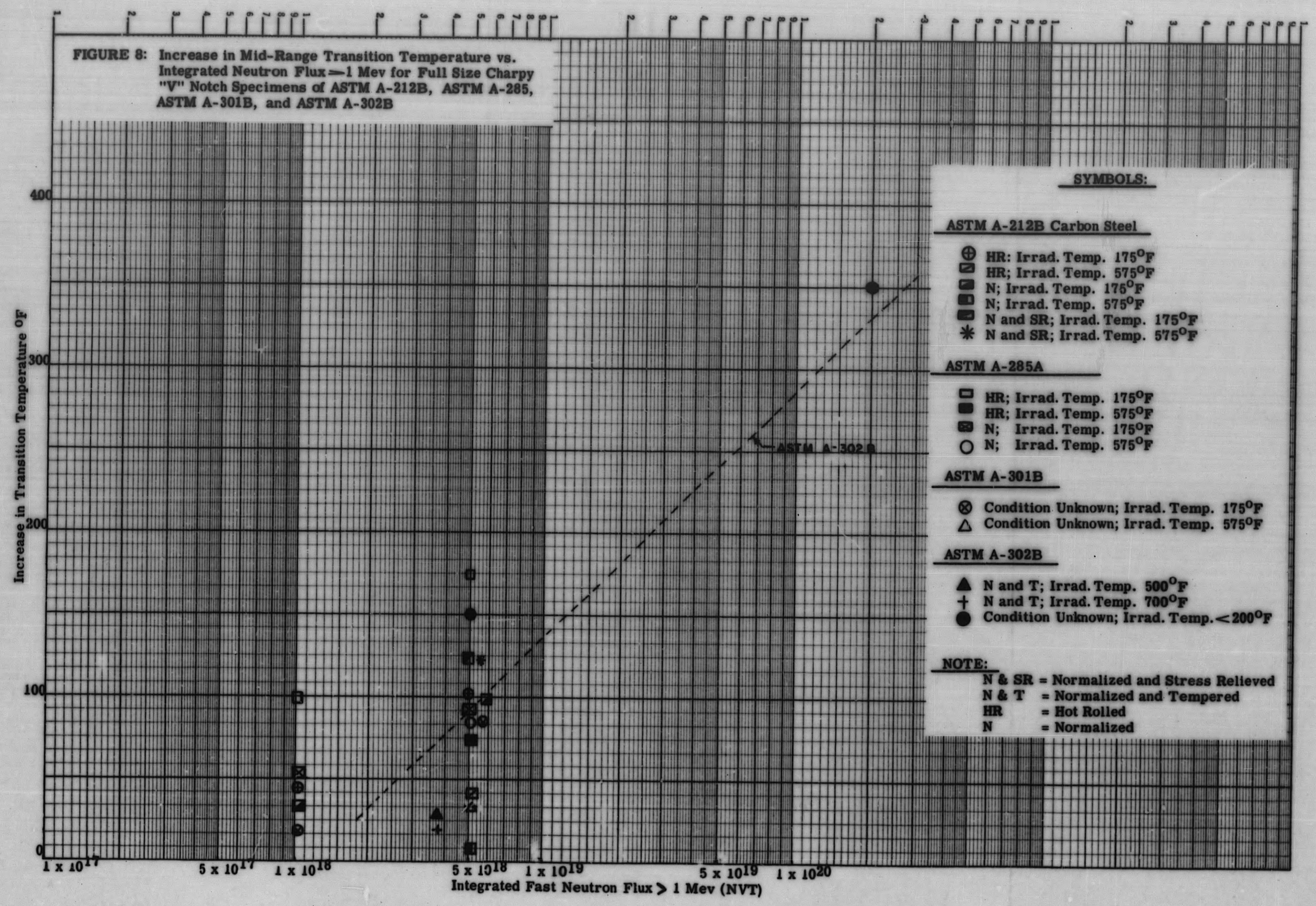




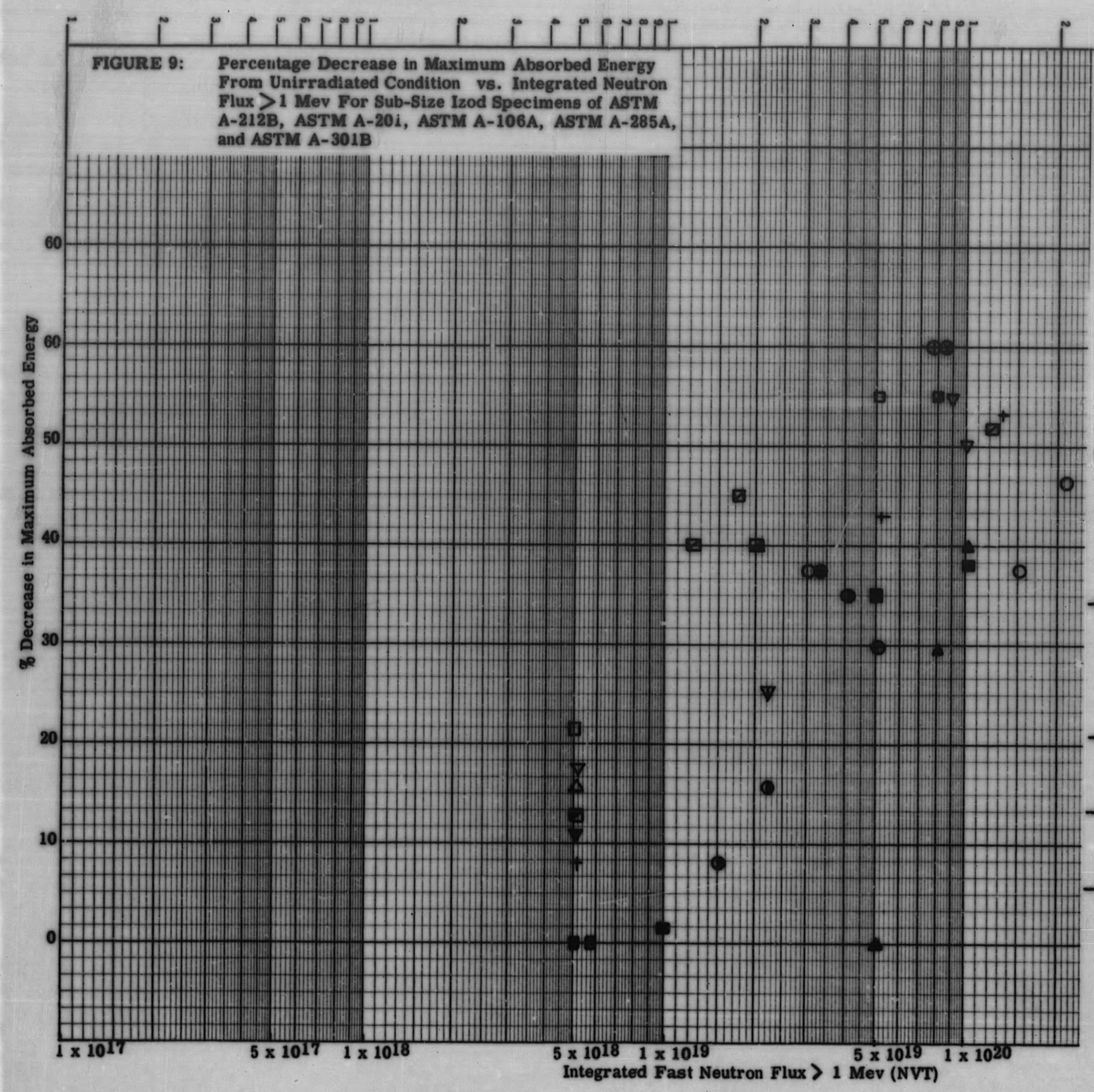

\section{iciciir i ifices ASTM A-212B \\ 口 HR; Irrad. Temp. $<200^{\circ} \mathrm{F}$ \\ N $1900^{\circ} \mathrm{F}$; Irrad. Temp. $<200^{\circ} \mathrm{F}$ \\ N $1900^{\circ} \mathrm{F}$; Irrad. Temp. $575^{\circ} \mathrm{F}$ \\ O N $1650^{\circ} \mathrm{F}$ and SR $1175^{\circ} \mathrm{F}$; Irrad. Temp, $\angle 200^{\circ} \mathrm{F}$ \\ $\mathrm{N} 1650^{\circ} \mathrm{F}$ and $\mathrm{SR} 1175^{\circ} \mathrm{F}$; Irrad. at $200^{\circ} \mathrm{F}$ followed by \\ Base Plate made to SA-300; Irrad. Temp. $<200^{\circ} \mathrm{F}$ Base Plate made to SA-300; Irrad. Temp. $600^{\circ} \mathrm{F}$ HAZ of base plate made to SA-300; Irrad. Temp. $<200 \%$ \\ and SR HAZ of base plate made to SA-300 Irrad. Temp. $<200^{\circ}$ \\ D E-7016 weld metal. No subsequent heat treatment. Irrad. Temp. $<200^{\circ} \mathrm{F}$. \\ E-7016 weld metal. SR, Q\&T Irrad. Temp. $<200^{\circ}$ F \\ ASTM A-201 \\ (1) HR; Irrad. Temp. $<200^{\circ} \mathrm{F}$ $\checkmark$ HR; Irrad. at $<200^{\circ} \mathrm{F}$, followed by a 6 hour anneal \\ HR; Irrad. at $<200^{\circ} \mathrm{F}$, followed by a 6 hour anneal at $635^{\circ} \mathrm{F}^{*}$ \\ ASTM A-106A \\ $\nabla$ N $1700^{\circ}$ F; coarse grain; Irrad. Temp. $-200^{\circ}$ \\ N $1700^{\circ}$; coarse grain; Irrad. Temp. $600^{\circ}$ \\ N $1700^{\circ}$; fine grain; Irrad. Temp. $200^{\circ}$ N $1700^{\circ}$; fine grain; Irrad. Temp. $600^{\circ} *$ ASTM A-285A \\ D HR Irrad. Temp. $<200^{\circ} \mathrm{F}$ \\ ASTM A-3C1B}

$\Delta \mathrm{N}$; Irrad. Temp. $<200^{\circ} \mathrm{F}$ NOTE

\section{HR $=$ Hot Rolled \\ SR = Stress Relieved \\ HAZ = Heat Affected Zone \\ Q6T = Quenched and Tempered}

- These samples were subject to an increase in maximum absorbed energy rather than a decrease. 


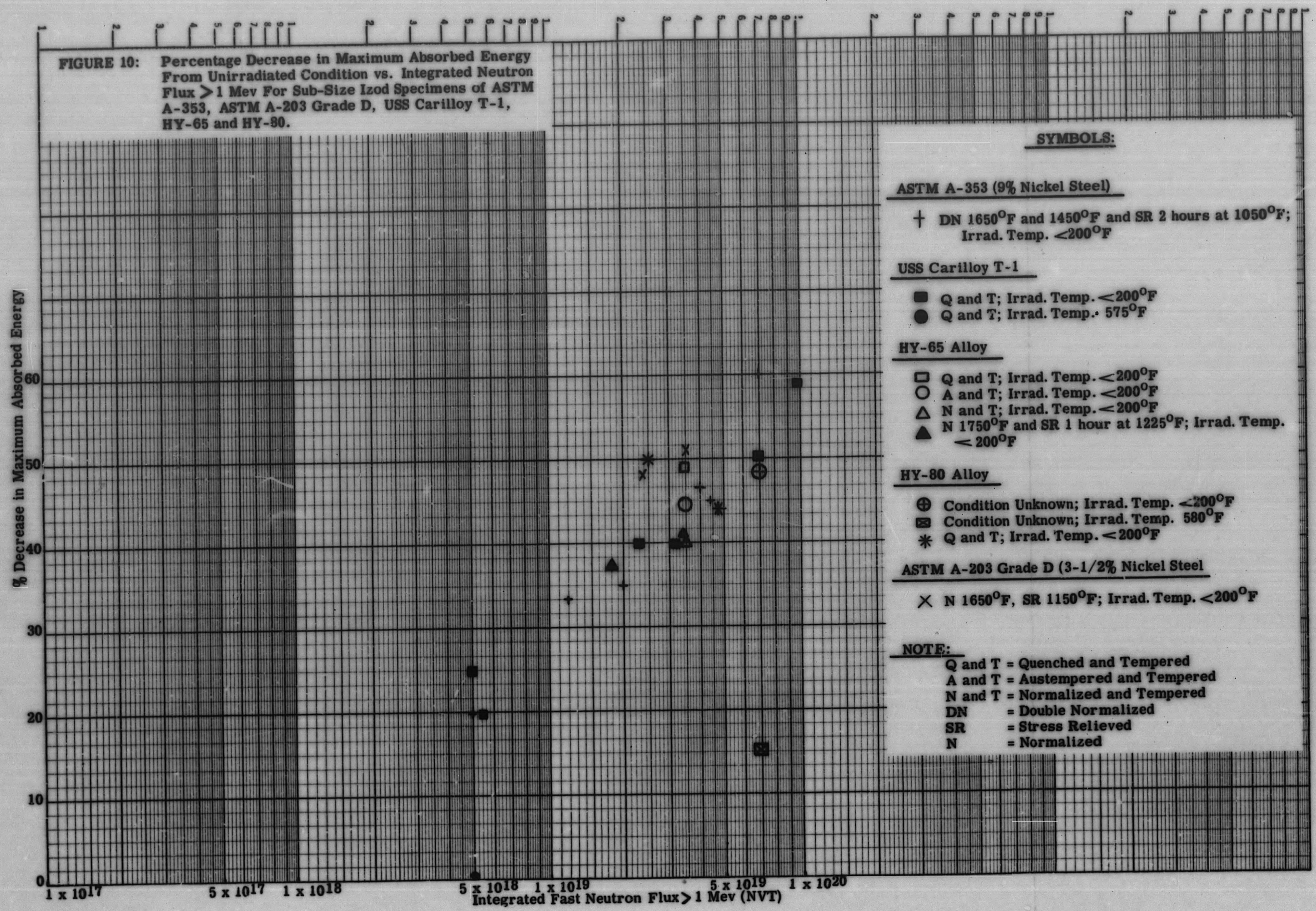




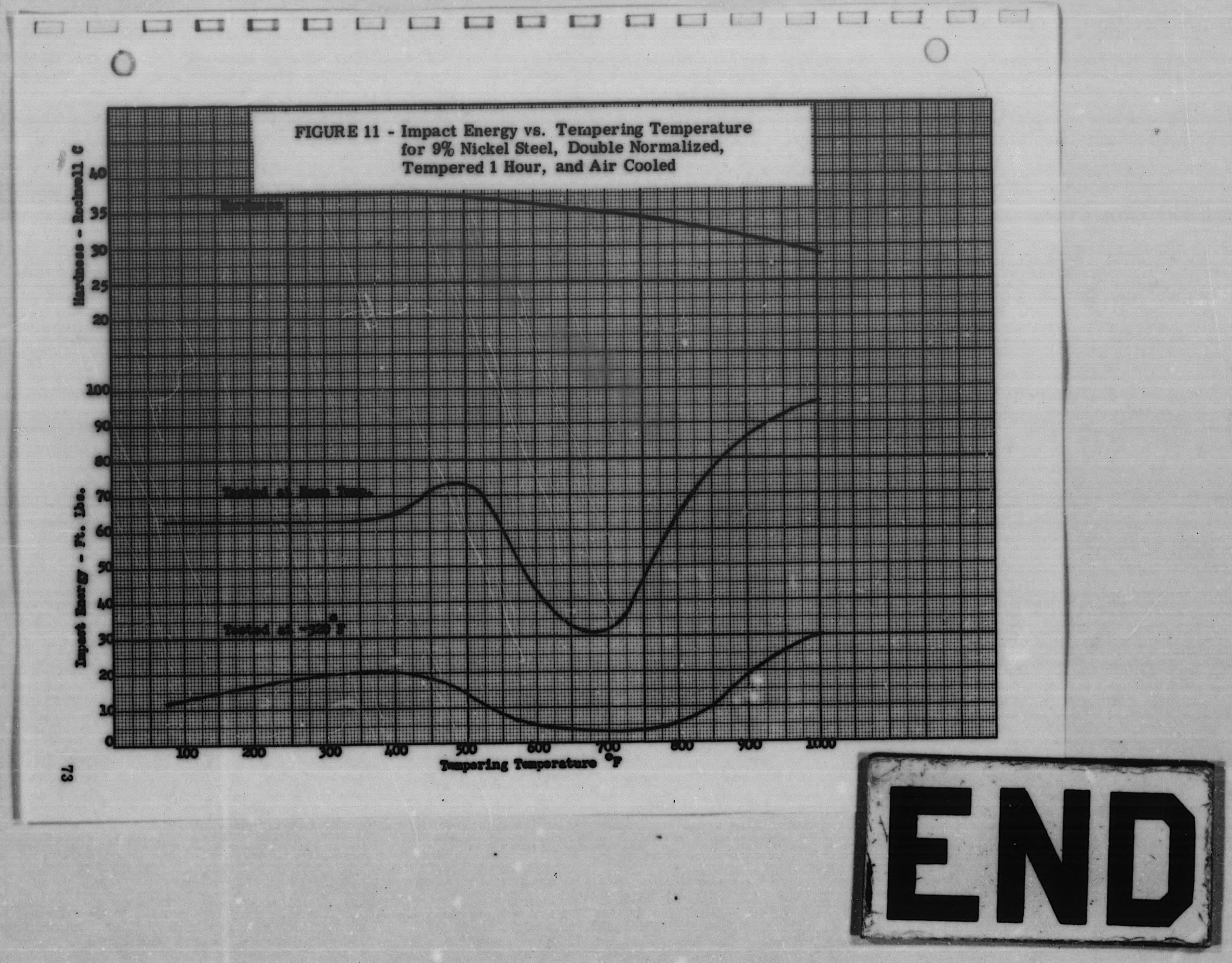

